\title{
THE PHYSIOLOGICAL AND DNA DAMAGE RESPONSE OF IN THE LICHEN HYPOGYMNIA PHYSODES TO UV AND HEAVY METAL STRESS
}

\author{
HAMUtOĞLU, R. ${ }^{1}$ - DERICI, M. K. ${ }^{2}$ - ARAS, E. S. ${ }^{3}$ - ASLAN, A. ${ }^{4,5}$ - CANSARAN-DUMAN, D. ${ }^{6 *}$ \\ ${ }^{1}$ Histology and Embryology Department, Faculty of Medicine, Cumhuriyet University, Sivas, \\ Turkey \\ ${ }^{2}$ Medical Pharmacology Department, Faculty of Medicine, Kırlkkale University, Kırıkkale, \\ Turkey \\ ${ }^{3}$ Biology Department, Faculty of Science, Ankara University, Ankara, Turkey \\ ${ }^{4}$ Department of Biology, Faculty of Arts and Science, Kyrgyz-Turkish Manas University, \\ Bishkek, Kryrgyzstan \\ ${ }^{5}$ Department of Pharmacology, Faculty of Pharmacy, Yüzüncü Yıl University, Van, Turkey \\ ${ }^{6}$ Biotechnology Institute, Ankara University, Ankara, Turkey \\ *Corresponding author \\ e-mail: dcansaran@yahoo.com; phone: +90-312-596-1032/2563
}

(Received $24^{\text {th }}$ Oct 2019; accepted $21^{\text {st }}$ Jan 2020)

\begin{abstract}
This work aims to determine the response of Hypogymnia physodes (L.) Nyl. (hooded tube lichen) collected in an unpolluted site (Yenice Forest in Karabük, Turkey) to stress conditions. In the present study, the effect of exposure to different heavy metals $\left(\mathrm{Cd}^{+2}, \mathrm{~Pb}^{+2}\right.$, and $\left.\mathrm{Cr}^{+6}\right)$ for different durations and UV radiations dosages on lichen was examined at the physiological and molecular levels. The effects of stress conditions were determined in the case of different parameters concerning heavy metal, protein, chlorophyll, and carotenoid contents and changes in the DNA profiles. According to the results obtained that exposure to heavy metals and UV radiations leads to a physiological response in a concentration and dose-dependent manner through differences in chlorophyll, protein content in heavy metals and UV treated lichen specimen. Furthermore, changes in RAPD assay and DNA methylation analysis showed that homologous nucleotide sequences in the genome from untreated and stress conditions treated lichen specimen showed different band patterns and methylation under heavy metals and UV stress. The results determined that lichen specimen suggest as a possible bioindicator able to measure the biological effects of heavy metal pollution and damage to UV radiation.
\end{abstract}

Keywords: lichen, UV radiations, metal uptake, chlorophyll content, DNA alteration

\section{Introduction}

Due to population and rapid economic growth and urbanization, air pollution creates a major threat both to the environment and living organisms in the world. Environmental Protection Agency (EPA) has reported that some pollutants are poisonous, and inhaling them, in particular, can rapidly increase problems in human health (Cheloni et al., 2014; Mateos et al., 2018). Environmental pollution caused by heavy metals is one of the most serious problems at a global extent (Pescott et al., 2015; Ares et al., 2017). Among all heavy metals, cadmium $\left(\mathrm{Cd}^{+2}\right)$, chromium $\left(\mathrm{Cr}^{+3}\right.$ and $\left.\mathrm{Cr}^{+6}\right)$ and lead $\left(\mathrm{Pb}^{+2}\right)$, in particular, cause an ever-increasing international concern. The excessive $\mathrm{Cr}^{+6}, \mathrm{Cd}^{+2}$ and $\mathrm{Pb}^{+2}$ concentrations in contaminated areas can give rise to a 
variety of problems, which is metal toxicity to mainly humans and animals (Frohnmeyer and Staiger, 2003). Another main problem in ecotoxicology is the damage of the stratospheric ozone layer due to anthropogenic activities, which results in increased UV radiation on the surface of the Earth and causes damage to the biological system (Singh et al., 2012). Pollutants and UV radiation interrupt metabolic activities at the cellular level and damage biological molecules such as proteins and nucleic acids (Pourrut et al., 2011).

In contrast to organic pollutants, heavy metals cannot be degraded through any known biological processes (Brown et al., 2005), and thus, there remains an urgent need for remediation of contaminated areas by environmentally friendly technology. An appropriate and cost-effective method to remove pollutants and UV radiation from the environment is needed. Biological methods, instead of physical and chemical methods, enable to direct assessment of environmental stressors. Thus, information obtained from biological data can be allowed to determinate the environmental impact of global problems on biological organisms. The solution to many global problems, such as bioremediation of toxic chemicals in the environment and decreasing the effect of UV radiation will require further research on cellular and molecular biology with biological organisms (Bah et al., 2011). For instance, Typha angustifolia shows protein changes when exposed to $\mathrm{Cr}^{+6}, \mathrm{Cd}^{+2}$ and $\mathrm{Pb}^{+2}$ heavy metals. Results of the study suggest that abiotic stress, such as heavy metal, temperature, drought and salt stress, induces changes in protein expression level in plants (Cho and Seo, 2005; Pandey et al., 2005). The liverwort (Lunularia cruciate) has been used to evaluate the effect of heavy metals on the cellular levels, including changes in the mRNA level (Basile et al., 2005). Lichen species have used to determinate the response of physiological and molecular mechanisms in stress conditions in recent years (Aras et al., 2010; Cansaran-Duman, 2011; Matos et al., 2015). Due to lichen species lack protective cuticle and roots, they can adsorb all metals directly from contaminated areas and ability to absorb in high quantity heavy metals in contaminated areas are usually used as model organisms for various purposes by the environmental area.

Damage to DNA may generate mutations, altered bases and strand breaks (Shugart and Theodorakis, 1994), and afterward, to carcinogenesis, teratogenesis and health disorders (Kurelec, 1993). Some researchers have reported that positively charged metal ions can react with negatively charged oxygen atoms located in both chains of the DNA in phosphate groups (Anastassopoulou, 2003). The DNA damage generated by environmental stress sources has been shown with various studies conducted in our laboratory (Cansaran-Duman et al., 2011; Cansaran and Aras, 2014; Vardar et al., 2014).

In recent years, some studies have shown that low UVB fluence rate is the cause of cellular changes in higher plants (Brown et al., 2005; Brown and Jenkins, 2008). It has been demonstrated that low UVB fluence rate responses involve specific receptors and appear to be photoregulatory. The changes caused by UV radiation on plant development, morphology and physiology have been observed in several studies (Mackerness, 2000; Frohnmeyer and Staiger, 2003; Jenkins, 2009; Hideg et al., 2013). Generally, energy-rich UV radiation gives rise to the formation of free radicals that damage DNA, proteins, and the damage of photosynthetic pigments (Hideg et al., 2013).

This study aimed to understand, predict and expand the knowledge of the possible biological response of Hypogymnia physodes lichen specimen to different types and 
exposure periods of both UV and heavy metal solutions on cellular organization and physiological responses by examining bioaccumulation performance. Firstly, we evaluated heavy metal contents, chlorophyll (chl-a, chl-b, total chl, and carotenoids) and protein content in response to different heavy metal accumulation and UV radiations exposure to lichen specimen. Secondly, RAPD and MSAP-AFLP techniques were examined in $H$. physodes for possible changes in the DNA exposed to different heavy metal solutions and UV radiations. Although the capacity of heavy metal accumulation on lichen specimen has been extensively studied, only a few studies to date have shown that lichen specimen exposes to UV radiations at molecular and biochemical levels and heavy metal accumulation. This is the first manuscript examining methyl profiles in lichen specimen. Thus, this study will provide a better understanding of the molecular mechanisms of cellular protection against different stress factors on lichen species.

\section{Materials and methods}

\section{Lichen sample and stress treatment}

All procedures were carried out at Ankara University Department of Biology Molecular Systematic Laboratory and Ankara University Biotechnology Institute Central Laboratory, Ankara, Turkey. Hypogymnia physodes lichen specimen was selected as suitable bioindicators due to it has a large thallus surface. The lichen specimen was obtained from the unpolluted area of Yenice Forest, Karabük, Turkey in $2011\left(41^{\circ} 10^{\prime} \mathrm{N}, 32^{\circ} 23^{\prime} \mathrm{E}\right)$. The sample collected from Yenice Forest was firstly washed and stored at appropriate conditions $\left(4^{\circ} \mathrm{C}\right)$ for a few days and sprayed distilled water. Then, the lichen specimen was sprayed constantly with distilled water in the laboratory. The sample was kept at room temperature for 2-3 h. During the treatments, thallus was placed in a climate chamber at $15{ }^{\circ} \mathrm{C}$, exposure a photosynthetic photon flux density (PPFD) of $75 \mu \mathrm{mol} \mathrm{m} \mathrm{m}^{-1}$ and a $16 \mathrm{~h}$ photoperiod. All analytical procedures were carried out at least three replicates $(n=3)$.

Two different stress treatments (exposure to heavy metals and UV radiations) were applied in the study. A schematic representation of stress treatments in lichen specimen was shown in Figure 1. H. physodes was subjected to $\mathrm{Pb}^{+2}, \mathrm{Cd}^{+2}$ and $\mathrm{Cr}^{+6}(30,60$ and $120 \mathrm{mg} / \mathrm{L})$ heavy metal stress for different time periods $(0.5,1,2,6,18,24,48$ and $72 \mathrm{~h})$. In brief, the stock solutions of $\mathrm{Cd}^{+2}, \mathrm{~Pb}^{+2}$ and $\mathrm{Cr}^{+6}(200 \mathrm{mg} / \mathrm{L})$ were prepared by dissolving a weighed quantity in deionized water. In this study, the required concentrations were prepared from the stock solution with dilution. Lichen thallus $(10 \mathrm{~g}$ weight) was immersed for an incubation period of $0.5,1,2,6,18,24,48$ and $72 \mathrm{~h}$. The lichen specimen was studied with three unexposed samples. The procedure followed for UV exposure; thallus sample placed in a petri dish was exposed to UV radiations at different doses of $4,8,12,20$ and $40 \mathrm{j} / \mathrm{cm}^{2}(352 \mathrm{~nm}, 50 \mathrm{~Hz}, 0.60 \mathrm{Amps})$ by using dosemeter at $25{ }^{\circ} \mathrm{C}$. Irradiation chamber BS-03 (Dr. Gröbel UV-Electronic $\mathrm{GmbH}$ ) and dosemeter were used to lichen for determining to expose to UV radiations (UVA, UVB, UVC, daylight, UVA + UVB, UVA + day light) ratios. The control (non-stressed) group was analyzed with molecular markers and was indicated as a 'control sample'. Negative control was also used to determine the presence of any contamination.

\section{Determination of heavy metals concentration}


The determination of heavy metal contents was performed from the previous study of Cansaran-Duman (2011). Lichen sample exposed to $\mathrm{Cd}^{+2}$ and $\mathrm{Pb}^{+2}$ heavy metals was collected at different time intervals. The sample was dried at $90{ }^{\circ} \mathrm{C}$ for $9 \mathrm{~h}$ and mineralization using $\mathrm{HNO}_{3}$ and $\mathrm{H}_{2} \mathrm{O}_{2}(2: 1$, v/v) under ultrasonication. The set of standard calibration curves with good linear regression and better relative standard deviations were achieved for $\mathrm{Cd}^{+2}$ and $\mathrm{Pb}^{+2}$ metals in $H$. physodes. $\mathrm{Cd}^{+2}$ and $\mathrm{Pb}^{+2}$ concentrations of lichen sample were analyzed using Flame Atomic Absorption Spectroscopy (FAAS; Instrument PM Avarta, GBC Scientific Equipment, Australia). Standard reference material, CRM 482 Lichen (P. furfuracea), was used in the study to determine whether within range of the recommended values. The measured recovery $\% \pm \mathrm{SD}$ for $\mathrm{Cd}^{+2}$ and $\mathrm{Pb}^{+2}$ in the added CRM 482 reference material were $98 \pm 7$, $99 \pm 6,98 \pm 3$, respectively. The recovery was about $100 \%$ for $\mathrm{Cd}^{+2}$ and $\mathrm{Pb}^{+2}$ in the lichen sample, and the results with the CRD 482 material suggested that sample preparation and analyses were accurate. The conventional spectrophotometric method of $\mathrm{Cr}^{+6}$ was analyzed via 1.5-diphenylcarbazide measured at $540 \mathrm{~nm}$ in acid solution (APHA, 1985).

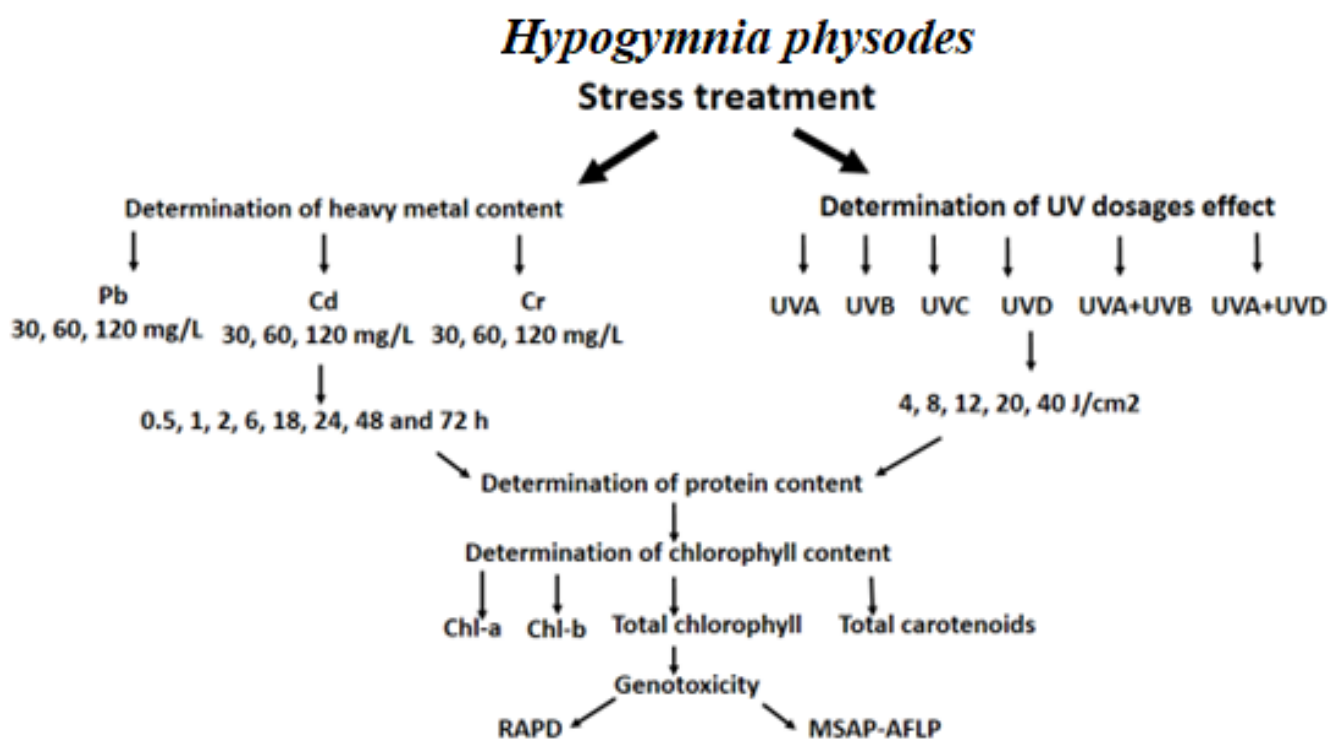

Figure 1. A schematic representation of the treatments in Hypogymnia physodes lichen specimen. In this study evaluated three different metal stress treatments $\left(\mathrm{Pb}^{+2}, \mathrm{Cd}^{+2}\right.$ and $\left.\mathrm{Cr}^{+6}\right)$ for eight different time periods $(0.5,1,2,6,18,24,48$ and $72 \mathrm{~h})$ and in five different $U V$ doses $\left(4,8,12,20,40 \mathrm{~J} / \mathrm{cm}^{2}\right.$ for UVA, UVB, UVC, daylight, UVA + UVB, UVA + daylight) in lichen sample. Also, the genotoxic effect of heavy metals and $U V$ radiations was investigated for lichen specimen by RAPD and DNA methylation analysis

\section{Determination of total soluble protein content}

Lichen specimen was homogenized (1:1, w/v) with $0.2 \mathrm{M}$ phosphate buffer $(\mathrm{pH} 7.0)$. The obtained homogenate was centrifuged at $27.000 \times g$ for $20 \mathrm{~min}$. The supernatant was removed after centrifugation period. The total soluble protein content was determined according to the Bradford method (Bradford, 1976), using bovine serum albumin (BSA) standard. The experiments were repeated three times $(n=3)$. 


\section{Determination of chlorophyll contents}

Unexposed lichen sample was immersed in distilled water for $5 \mathrm{~min}$ to obtain photosynthetic activity. Lichen specimen was exposed to $\mathrm{Cd}^{+2}, \mathrm{~Pb}^{+2}$, and $\mathrm{Cr}^{+6}$ heavy metal solution and different UV radiations, and the chlorophyll content were determined by taking samples from this sample exposed to stress at certain time intervals (Fig. 1). Contents of chlorophyll a, chlorophyll $\mathrm{b}$, total chlorophyll, chlorophyll $\mathrm{a} / \mathrm{b}$, and total carotenoids were spectrophotometrically determined (Metzner et al., 1965). Briefly, a 40-60 mg lichen sample was kept within $3 \mathrm{ml}$ of dimethylsulfoxide (DMSO) for $1 \mathrm{~h} \mathrm{at}$ $65^{\circ} \mathrm{C}$ in the dark. Lichen sample kept in the dark for $1 \mathrm{~h}$ was centrifuged at $12000 \mathrm{~g}$ for $10 \mathrm{~min}$ at $20{ }^{\circ} \mathrm{C}$. The supernatant was transferred to a fresh tube, and then, spectrophotometric measurements were taken at wavelengths of 644 (chl-a), 663 (chlb), 452 (total chl) and $470 \mathrm{~nm}$ (Chls) (Ronen and Galun, 1984; Wellburn, 1994). This process was performed triplicate $(n=3)$. Each analysis was replicated three times.

\section{Genomic DNA extraction and RAPD assay}

H. physodes was exposed to $\mathrm{Pb}^{+2}, \mathrm{Cd}^{+2}$ and $\mathrm{Cr}^{+6}(30,60$ and $120 \mathrm{mg} / \mathrm{L})$ heavy metal stress for different periods $(0.5,1,2,6,18,24,48$ and $72 \mathrm{~h})$, UV radiations and DNA of the lichen sample was extracted (Fig. 1). DNA extraction was performed according to the protocol defined by Aras and Cansaran (2006). Concentration and purity of the DNA extracted are measured at OD 260 and with a $260 \mathrm{~nm} / 280 \mathrm{~nm}$ absorbance ratio by nanodrop (NanoDrop ND-1000 Spectrophotometer, Thermo Scientific, Wilmington, USA), respectively.

Primer screening for RAPD analysis was performed using 10 primers. The six of the ten primers amplified clear and reproducible bands in heavy metal stress and UV stress, respectively. PCR components were determined as follows; $200 \mathrm{ng}$ genomic DNA, $2.5 \mu \mathrm{L} 10 \mathrm{X}$ reaction buffer, $3.0 \mathrm{mM} \mathrm{MgCl}$, $20 \mathrm{mM}$ dNTPs, $0.3 \mathrm{mM}$ primer, and 0.5 unit of Taq polymerase (Promega, Madison, USA), and $\mathrm{ddH}_{2} \mathrm{O}$ was added to the final volume of $25 \mu \mathrm{L}$. Negative controls were used in all PCR reactions. The PCR program operated with the following steps: $95{ }^{\circ} \mathrm{C}$ for $30 \mathrm{~s}$ for denaturation, $36{ }^{\circ} \mathrm{C}$ for $1 \mathrm{~min}$ at 35 cycles for annealing step, $72{ }^{\circ} \mathrm{C}$ for 2 min for extension and a final extension at $72{ }^{\circ} \mathrm{C}$ for 10 min. PCR products were loaded on $1.5 \%$ agarose gels and run at $80 \mathrm{~V}$ for $4 \mathrm{~h}$.

\section{MSAP-AFLP analysis}

In the MSAP-AFLP analysis was used OPC10 primer which is one of the primers giving sharp bands during RAPD analysis. The genomic DNA (200 ng) of the two stress exposed samples were separately digested with EcoR I/Msp I and EcoR I/Hpa II restriction enzymes at $37^{\circ} \mathrm{C}$ for $2.0 \mathrm{~h}$. Subsequently, the digested aliquot was ligated to specific adopters for examined restriction enzymes because it was applied to avoid reconstruction of restriction sites one for EcoR I sticky ends and other for Msp I or Hpa II sticky ends, at $20{ }^{\circ} \mathrm{C}$ for $90 \mathrm{~min}$. The ligated DNA was diluted with Tris-EDTA buffer, and then the diluted products were amplified using different combinations of EcoR I and Msp I or Hpa II primer each with three selective nucleotides at 5' and 3', respectively. MSAP-AFLP analyses were conducted following the method described by Mastan et al. (2012). Briefly, selective amplifications were performed at $65^{\circ} \mathrm{C}$ temperature for the first cycle, the annealing temperature was successively reduced by $0.7^{\circ} \mathrm{C}$ for the other 11 subsequent cycles. The remaining 23 from 45 cycles were run at $56{ }^{\circ} \mathrm{C}$ annealing temperature. After the formamide dye added PCR product, the 
electrophoresis assay was run. The gels were stained with silver nitrate and scanned (Bassam et al., 1991). To test the reproducibility of the AFLP-PCR, the experiments were repeated at least twice for each primer, faint bands were not involved in this study.

\section{Statistical analysis}

The results of heavy metal content, ratio of UV radiation and total soluble protein content of the lichen specimen were evaluated by multifactor analysis of variance (univariate ANOVA) or Student's t-test followed by posthoc Tukey test as appropriate (SPSS for Windows version 11.0) to display the effects of both stress sources on the exposed lichen.

Chlorophyll a, b, total chlorophyll and carotenoids were calculated by the following equations by Shakoor et al. (2014). The experiments were repeated three times $(n=3)$ and then evaluated with multifactor analysis of variance (ANOVA).

\section{Estimation of profiling scoring and data analyses for RAPD assay}

The RAPD analysis of the results was evaluated by considering the number of bands, which appear in the control (non-stressed) sample. Polymorphism calculated in RAPD profiles included the disappearance and appearance bands when compared with the nonstressed sample (Atienzar et al., 1999; Liu et al., 2005). Each polymorphic DNA band on the gel was treated as an individual locus and scored for their presence (1) or absence (0). Genomic template stability (GTS\%) was calculated as followed by Atienzar et al. (1999). Changes in RAPD patterns were evaluated as decreases in GTS, compare with the number of RAPD profiles exposed to a different stress condition, and profiles obtained from the control samples.

\section{Estimation of profiling scoring and data analyses for methylation analyses}

MSAP data analysis was scored reproducible bands. All the amplified bands obtained from the MSAP-AFLP analysis were divided into four methylation types based on the presence or absence of groups as indicated by Li et al. (2009). According to this classification, the bands indicating each methylation type (I, II, III, and IV) were counted and placed in their location in Table 1.

The percentage of methylation was evaluated as the number of methylated bands $x$ 100 by dividing the total number of bands. The percentage of methylation polymorphism was calculated using the formula (=number of polymorphic methylated bands $\times 100 /$ number of methylated bands).

Table 1. Methylation types created by the cutting ability of HPAII and MspI restriction enzymes

\begin{tabular}{c|c|c|c}
\hline Methylation type & Methylation pattern & HpaII & MspI \\
\hline Type I & CCGG CGG GGCC GGCC & Active & Active \\
Type II & CCGG GGCC & Active & Inactive \\
Type III & C $\underline{C} G$ GGCC & Inactive & Active \\
Type IV & CCGG GGCC & Inactive & Inactive \\
\hline
\end{tabular}




\section{Results}

We analyzed $H$. physodes lichen specimen for three different metal stress treatments were applied $\left(\mathrm{Pb}^{+2}, \mathrm{Cd}^{+2}\right.$ and $\left.\mathrm{Cr}^{+6}\right)$ in three different doses $(30,60$ and $120 \mathrm{mg} / \mathrm{L})$ for eight different periods $(0.5,1,2,6,18,24,48$ and $72 \mathrm{~h})$. The same concerns exposure to UV radiations on lichen specimen examined six combinations of UV radiations (UVA, UVB, UVC, daylight, UVA + UVB, UVA + daylight) with five different doses of 4, 8, 12,20 and $40 \mathrm{j} / \mathrm{cm}^{2}$. Subsequently, in the analyzed sample, heavy metal, total soluble protein, chlorophyll a, chlorophyll b, total chlorophyll, and total carotenoids contents were measured (Fig. 1). The changes of DNA profile exposed to different heavy metals and UV radiations determined RAPD and DNA methylation analysis assays.

\section{Determination of heavy metal contents in lichen specimen}

The $30 \mathrm{mg} / \mathrm{L} \mathrm{Cd} \mathrm{Cd}^{+2}$ metal absorption by $H$. physodes was very fast and optimum equilibrium was reached at $30 \mathrm{~min}(\mathrm{P}<0.05)$ (Fig. 2; Table 2). H. physodes was found to have an optimum absorption rate of $70.5 \%$ after $30 \mathrm{mg} / \mathrm{L} \mathrm{Pb}^{+2}$ applications in $72 \mathrm{~h}$ $(\mathrm{P}<0.05)$. It was noticed that $60 \mathrm{mg} / \mathrm{L} \mathrm{Cr}^{+6}$ exposure significantly reduced $(79.9 \%)$ heavy metal content in $H$. physodes $(47.8 \mathrm{mg} / \mathrm{L})$ in $72 \mathrm{~h}$ when compared to unexposed sample $(59.8 \mathrm{mg} / \mathrm{L})(\mathrm{P}<0.05)$. The highest absorption efficiency $(94.2 \%)$ was obtained at $120 \mathrm{mg} / \mathrm{L} \mathrm{Cr}^{+6}$ for $72 \mathrm{~h}$ in $H$. physodes lichen specimen $(\mathrm{P}<0.05)$.

The highest absorption efficiency was achieved as about $92.2 \%, 95.1 \%$ and $95.5 \%$ using 30, 60 and $120 \mathrm{mg} / \mathrm{L} \mathrm{Cr}^{+6}$ for $18 \mathrm{~h}$, respectively. According to the results of 30,60 and $120 \mathrm{mg} / \mathrm{L} \mathrm{Pb}^{+2}$ application in lichen specimen, the absorption capacity percentage decreased from $43.4 \%$ to $34.5 \%$ as $H$. physodes was applied to $30 \mathrm{mg} / \mathrm{L} \mathrm{Pb}^{+2}$ for $24 \mathrm{~h}$. $60 \mathrm{mg} / \mathrm{L} \mathrm{Pb}{ }^{+2}$ heavy metal absorption decreased from $58.1 \%$ for $24 \mathrm{~h}$ in $H$. physodes. At $120 \mathrm{mg} / \mathrm{L} \mathrm{Pb}^{+2}$, the absorption efficiency was found to be low in $H$. physodes $(59.2 \%)$ for $24 \mathrm{~h}(\mathrm{P}<0.05)$.

The optimum absorption capacity against 30,60 and $120 \mathrm{mg} / \mathrm{L} \mathrm{Cd}^{+2}$ heavy metal stress was found as $43.8 \%$ for $30 \mathrm{~min}, 63.3 \%$ for $12 \mathrm{~h}$ and $57.5 \%$ for $6 \mathrm{~h}$ in $\mathrm{H}$. physodes, respectively $(\mathrm{P}<0.05)$.

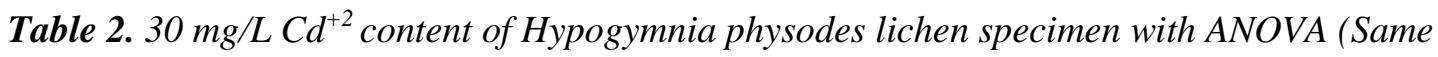
letters in a column indicate the absence of significant differences at $P<0.05$ by ANOVA)

\begin{tabular}{|c|c|c|c|c|c|c|c|c|}
\hline \multirow{2}{*}{ Samples } & \multirow{2}{*}{$\mathbf{N}$} & \multirow{2}{*}{ Mean } & \multirow{2}{*}{$\begin{array}{c}\text { Std. } \\
\text { deviation }\end{array}$} & \multirow{2}{*}{ Std. error } & \multicolumn{2}{|c|}{$\begin{array}{l}\text { 95\% confidence interval } \\
\text { for mean }\end{array}$} & \multirow{2}{*}{ Min } & \multirow{2}{*}{ Max } \\
\hline & & & & & $\begin{array}{l}\text { Lower } \\
\text { bound }\end{array}$ & $\begin{array}{l}\text { Upper } \\
\text { bound }\end{array}$ & & \\
\hline Control & 3 & $29.7000-$ & .10000 & .05774 & 29.4516 & 29.9484 & 29.60 & 29.80 \\
\hline $30 \mathrm{~min}$ & 3 & 12.9000 & .20000 & .11547 & 12.4032 & 13.3968 & 12.70 & 13.10 \\
\hline $1 \mathrm{~h}$ & 3 & 11.6000 & .10000 & .05774 & 11.3516 & 11.8484 & 11.50 & 11.70 \\
\hline $2 \mathrm{~h}$ & 3 & 12.1000 & .10000 & .05774 & 11.8516 & 12.3484 & 12.00 & 12.20 \\
\hline $6 \mathrm{~h}$ & 3 & 11.8000 & .30000 & .17321 & 11.0548 & 12.5452 & 11.50 & 12.10 \\
\hline $18 \mathrm{~h}$ & 3 & 11.2000 & .20000 & .11547 & 10.7032 & 11.6968 & 11.00 & 11.40 \\
\hline $24 \mathrm{~h}$ & 3 & 10.9000 & .20000 & .11547 & 10.4032 & 11.3968 & 10.70 & 11.10 \\
\hline $48 \mathrm{~h}$ & 3 & 10.9000 & .40000 & .23094 & 9.9063 & 11.8937 & 10.50 & 11.30 \\
\hline $72 \mathrm{~h}$ & 3 & 10.9000 & .30000 & .17321 & 10.1548 & 11.6452 & 10.60 & 11.20 \\
\hline \multirow{2}{*}{ Total } & 27 & 13.5556 & 5.85526 & 1.12685 & 11.2393 & 15.8718 & 10.50 & 29.80 \\
\hline & Sum of & df & Mean & $\mathbf{F}$ & Sig. & & & \\
\hline
\end{tabular}




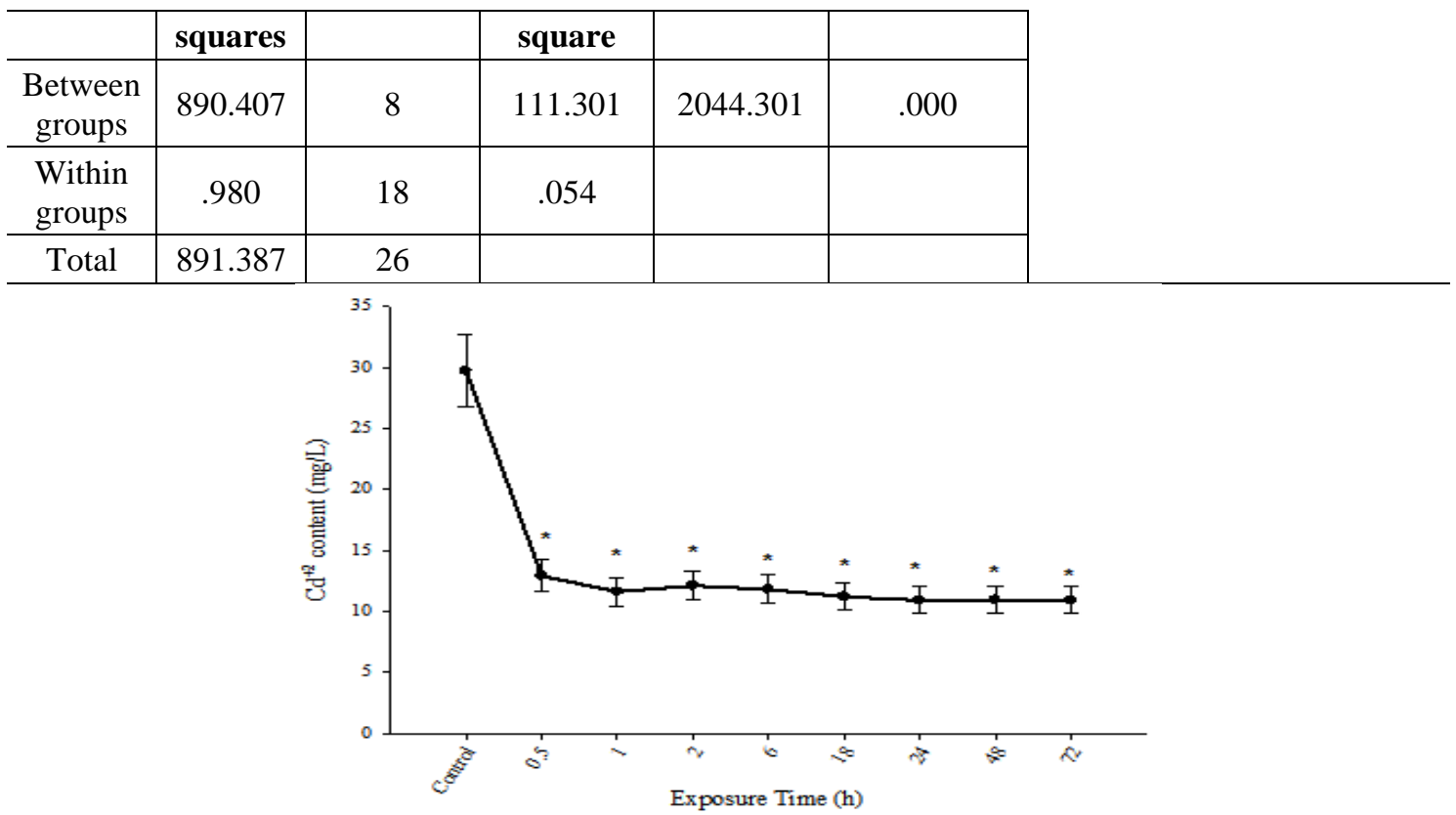

Figure 2. The time-concentration curve of $\mathrm{Cd}^{+2}$ content of the stock solution that exposed to Hypogymnia physodes. $\left(^{*}=\right.$ statistically different from control $(P<0.05) \mathrm{Cd}^{+2}$ removal by $\mathrm{H}$. physodes at initial $\mathrm{Cd}^{+2}$ concentration for $72 \mathrm{~h}$

\section{Determination of protein content in lichen specimen}

\section{Effect of heavy metals on protein content}

Protein content decreased with the increase in the concentration of heavy metals in $H$. physodes at the examined time range (30 min-72 h). Maximum protein content in $H$. physodes was increased for $30 \mathrm{mg} / \mathrm{L} \mathrm{Cr}^{+6}$ and $30 \mathrm{mg} / \mathrm{L} \mathrm{Cd}^{+2}$ until $30 \mathrm{~min}$; however, there was a significant decrease in protein content afterward (from 60 min to $72 \mathrm{~h}$ ) $(\mathrm{P}<0.05)$. Protein content of lichen specimen was also significantly increased at both heavy metal stress levels $\left(60 \mathrm{mg} / \mathrm{L} \mathrm{Cr}^{+6}\right.$ and $\mathrm{Cd}^{+2}$ heavy metals) for $30 \mathrm{~min}(\mathrm{P}<0.05)$. Protein content of $H$. physodes decreased all concentrations of $\mathrm{Pb}^{+2}$ stress when compared with the unexposed sample. The results of this study showed that the protein content of lichen specimen significantly decreased $(\mathrm{P}<0.05)$ by $120 \mathrm{mg} / \mathrm{L}$ concentration of $\mathrm{Cr}^{+6}$ (Table 3) and $\mathrm{Cd}^{+2}$ at $1 \mathrm{~h}$ after treatment $(0.023 \mathrm{mg} / \mathrm{L}$, respectively). However, the protein content of $H$. physodes significantly decreased by $120 \mathrm{mg} / \mathrm{L} \mathrm{Pb}^{+2}$ exposure for $1 \mathrm{~h}$ when compared with the unexposed lichen sample (20.73 and 19.23, 19.9 and $18.32 \mathrm{mg} / \mathrm{L}$, respectively) $(\mathrm{P}<0.05)$. Protein content significantly decreased after from 2 to $72 \mathrm{~h}$ exposure to $120 \mathrm{mg} / \mathrm{L} \mathrm{Pb}^{+2}$.

\section{Effect of $U V$ radiations on protein content}

The protein content of $H$. physodes significantly decreased at $40 \mathrm{j} / \mathrm{cm}^{2}$ among the other four UV radiations. Exposure to $40 \mathrm{j} / \mathrm{cm}^{2} \mathrm{UVA}+\mathrm{UVB}$ radiations, protein content significantly decreased by $28 \%$ in $H$. physodes ( $\mathrm{P}<0.05)$, similarly after the 4, 8, 12 and $20 \mathrm{j} / \mathrm{cm}^{2} \mathrm{UV}$ radiations exposure decreased protein content of $H$. physodes. The lowest UVB radiation $\left(4 \mathrm{j} / \mathrm{cm}^{2}\right)$ exposure was recorded as $0.0470 \mathrm{mg} / \mathrm{L}$ protein content and the highest UV radiations exposure $\left(40 \mathrm{j} / \mathrm{cm}^{2}\right)$ was measured as $0.0157 \mathrm{mg} / \mathrm{L}$ protein content in $H$. physodes when compared to unexposed sample $(0.0505 \mathrm{mg} / \mathrm{L})(\mathrm{P}<0.05)$. 


\section{Determination of chlorophyll content}

\section{Effect of heavy metals on chlorophyll-a content}

The results of the study showed that the chl-a content was significantly decreased by 30,60 and $120 \mathrm{mg} / \mathrm{L}$ concentration of $\mathrm{Cr}^{+6}, \mathrm{~Pb}^{+2}$ and $\mathrm{Cd}^{+2}$ after $2 \mathrm{~h}$ exposure (15.42 and $14.46,14.55$ and $11.49 \mathrm{mg} \mathrm{g}^{-1}$, respectively) $(\mathrm{P}<0.05) .120 \mathrm{mg} / \mathrm{L} \mathrm{Cr}^{+6}$ exposure for $2 \mathrm{~h}$ significantly decreased the chl-a content of $H$. physodes by $18 \%\left(0.404 \mathrm{mg} \mathrm{g}^{-1}\right)$ $(\mathrm{P}<0.05)$.

Table 3. Protein content of exposing to $120 \mathrm{mg} / \mathrm{L} \mathrm{Cr}{ }^{+6}$ of Hypogymnia physodes lichen specimen with ANOVA (Same letters in a column indicate the absence of significant differences at $P<0.05$ by ANOVA)

\begin{tabular}{|c|c|c|c|c|c|c|c|c|}
\hline \multirow{2}{*}{ Samples } & \multirow{2}{*}{$\mathbf{N}$} & \multirow{2}{*}{ Mean } & \multirow{2}{*}{$\begin{array}{c}\text { Std. } \\
\text { deviation }\end{array}$} & \multirow{2}{*}{ Std. error } & \multicolumn{2}{|c|}{$\begin{array}{l}95 \% \text { confidence } \\
\text { interval for mean }\end{array}$} & \multirow{2}{*}{ Min } & \multirow{2}{*}{ Max } \\
\hline & & & & & $\begin{array}{l}\text { Lower } \\
\text { bound }\end{array}$ & $\begin{array}{l}\text { Upper } \\
\text { bound }\end{array}$ & & \\
\hline Control & 3 & .0176289 & .00003006 & .00001736 & .0175542 & .0177035 & .01760 & .01766 \\
\hline $30 \mathrm{~min}$ & 3 & .017689 & .00002009 & .00001160 & .0178190 & .0179188 & .01785 & .01789 \\
\hline $1 \mathrm{~h}$ & 3 & . 0231703 & .00002001 & .00001155 & .0231206 & .0232200 & .02315 & .02319 \\
\hline $2 \mathrm{~h}$ & 3 & .0145604 & .00006000 & .00003464 & .0144114 & .0147095 & .01450 & .01462 \\
\hline $6 \mathrm{~h}$ & 3 & 0101416 & .00004010 & .00002315 & .0100420 & .0102413 & .01010 & .01018 \\
\hline $18 \mathrm{~h}$ & 3 & .0132290 & .00003005 & .00001735 & .0131543 & .0133036 & .01320 & .01326 \\
\hline $24 \mathrm{~h}$ & 3 & 0116093 & .00001008 & .00000582 & .0115842 & .0116343 & .01160 & .01162 \\
\hline $48 \mathrm{~h}$ & 3 & . 0097306 & .00003002 & .00001733 & .0096560 & .0098051 & .00970 & .00976 \\
\hline $72 \mathrm{~h}$ & 3 & .0124985 & .00007005 & .00004044 & .0123245 & .0126725 & .01243 & .01257 \\
\hline \multirow[t]{2}{*}{ Total } & 27 & .0144930 & .00418853 & .00080608 & .0128361 & .0161500 & .00970 & .02319 \\
\hline & $\begin{array}{l}\text { Sum of } \\
\text { squares }\end{array}$ & df & $\begin{array}{c}\text { Mean } \\
\text { square }\end{array}$ & $\mathbf{F}$ & Sig. & & & \\
\hline $\begin{array}{c}\text { Between } \\
\text { groups }\end{array}$ & .000 & 8 & .000 & 37374.901 & .000 & & & \\
\hline $\begin{array}{l}\text { Within } \\
\text { groups }\end{array}$ & .000 & 18 & .000 & & & & & \\
\hline Total & .000 & 26 & & & & & & \\
\hline
\end{tabular}

\section{Effect of $U V$ radiations on chlorophyll-a content}

In UV radiations exposure, chl-a content of the unexposed sample of $H$. physodes was determined as $2.300 \mathrm{mg} \mathrm{g}^{-1}$. In terms of the applied stress level among all UV radiations types (UVA, UVB, UVC, daylight, UVA + daylight, UVA + UVB), the highest increase was observed at $40 \mathrm{j} / \mathrm{cm}^{2}(\mathrm{p}<0.05)$. After the implementation of $40 \mathrm{j} / \mathrm{cm}^{2} \mathrm{UVA}+\mathrm{UVB}$ radiations level, the highest chl-a content increase $\left(10.760 \mathrm{mg} \mathrm{g}^{-}\right.$ $\left.{ }^{1}\right)$ was observed about 5 fold when compared to the unexposed sample $\left(2.300 \mathrm{mg} \mathrm{g}^{-1}\right)$ $(p<0.05)$. In contrast, exposure to UVA radiation alone at a dose of $40 \mathrm{j} / \mathrm{cm}^{2}$ increased the amount of the lowest chl-a $\left(2.742 \mathrm{mg} \mathrm{g}^{-1}\right)(\mathrm{p}<0.05)$. 


\section{Effect of heavy metals on chlorophyll-b content}

This study was determined the changes in chlorophyll-b content after exposure to heavy metals and UV radiations compared to the unexposed sample. The results of the study showed that chl-b content of $H$. physodes unexposed sample $\left(1.518 \mathrm{mg} \mathrm{g}^{-1}\right)$ significantly decreased with 30,60 and $120 \mathrm{mg} / \mathrm{L}$ concentration of $\mathrm{Cr}^{+6}, \mathrm{~Pb}^{+2}$ and $\mathrm{Cd}^{+2}$ after $48 \mathrm{~h}$ treatment $(\mathrm{P}<0.05)$. After 30,60 and $120 \mathrm{mg} / \mathrm{L} \mathrm{Pb}^{+2}$ treatments, the highest decrease rate at all concentrations when compared to the unexposed specimen was determined as $0.013,0.209$ and $0.057 \mathrm{mg} \mathrm{g}^{-1}$, respectively $(\mathrm{p}<0.05)$.

\section{Effect of $U V$ radiations on chlorophyll-b content}

$H$. physodes lichen specimen was observed 1.629, 2.873, 2.659, 2.229, 2.033 and $2.853 \mathrm{mg} \mathrm{g}{ }^{-1}$ chl-b content exposed to $8 \mathrm{j} / \mathrm{cm}^{2}$ UVA, UVB, UVC, daylight, $\mathrm{UVA}+\mathrm{UVB}, \mathrm{UVA}$ + day light when compared to the unexposed sample $\left(1.518 \mathrm{mg} \mathrm{g}^{-}\right.$ $\left.{ }^{1}\right)$, respectively.

\section{Effect of heavy metals on total chlorophyll content}

Total chlorophyll content in the unexposed sample in $H$. physodes was observed as $3.818 \mathrm{mg} \mathrm{g}^{-1}$. The optimum result of total chlorophyll content in $H$. physodes was obtained at three heavy metal exposures $\left(\mathrm{Cr}^{+6}, \mathrm{~Pb}^{+2}\right.$, and $\left.\mathrm{Cd}^{+2}\right)$ and concentrations (30, 60 and $120 \mathrm{mg} / \mathrm{L}$ ) after a $60 \mathrm{~min}$ treatment. The highest decrease rates $\mathrm{of}^{\mathrm{C}} \mathrm{Cr}^{+6}$ heavy metal among all concentrations were observed as $0.857,1.130$ and $0.583 \mathrm{mg} \mathrm{g}^{-1}$ in $H$. physodes lichen specimen, respectively $(\mathrm{P}<0.05)$.

\section{Effect of $U V$ radiations on total chlorophyll content}

Total chlorophyll content of $H$. physodes was observed as 4.341 and $5.394 \mathrm{mg} \mathrm{g}^{-1}$ expose to $8 \mathrm{j} / \mathrm{cm}^{2} \mathrm{UVA}+$ day light radiations. The highest content of total chlorophyll was determined as $14.923,12.989,12.159$ and $16.010 \mathrm{mg} \mathrm{g}^{-1}$ after exposure to $20 \mathrm{j} / \mathrm{cm}^{2}$ UVB, UVC, UVA + daylight, and UVA + UVB radiations, respectively $(\mathrm{p}<0.05)$. Especially, after the $20 \mathrm{j} / \mathrm{cm}^{2} \mathrm{UVA}+\mathrm{UVB}$ radiations treatment, the maximum decrease of total chlorophyll content $\left(16.010 \mathrm{mg} \mathrm{g}^{-1}\right)$ was observed in $H$. physodes, when compared to the unexposed sample $\left(3.818 \mathrm{mg} \mathrm{g}^{-1}\right)(\mathrm{P}<0.05)$.

\section{Effect of heavy metals on the ratio of chlorophyll $a / b$}

Variations in the ratio of chlorophyll $\mathrm{a} / \mathrm{b}$ were caused by increasing lichen metal content. The ratio of chlorophyll a/b in $H$. physodes exposed to 30,60 and $120 \mathrm{ppm} \mathrm{Cr}^{+6}$ heavy metal stress showed a significant decrease after $30 \mathrm{~min}$ of all three heavy metal treatments $(\mathrm{p}<0.05)$. Exposed to $30 \mathrm{ppm} \mathrm{Cd}^{+2}$ and $\mathrm{Pb}^{+2}$ heavy metal stress in $H$. physodes lichen specimen, the treatments showed a marked increase in the ratio of chlorophyll a/b $\left(86.02 \mathrm{mg} \mathrm{g}^{-1}\right)$ as a result of 18 and $24 \mathrm{~h}$, respectively $(\mathrm{p}<0.05)$. After treatments, the ratio is gradually decreasing towards the lowest level.

\section{Effect of $U V$ radiations on the ratio of chlorophyll $a / b$}

An increase in the ratio of chlorophyll a/b was observed after $4 \mathrm{j} / \mathrm{cm}^{2}$ treatment in $H$. physodes lichen specimen exposed to UVB radiation. 


\section{Determination of total carotenoid content}

\section{Effect of heavy metals on total carotenoid content}

The content of total carotenoid in the control sample of $H$. physodes was observed as $0.092 \mathrm{mg} \mathrm{g}^{-1}$. The optimum time of after all heavy metal exposure was determined at $18 \mathrm{~h}$. All examined heavy metal concentrations $(30,60$ and $120 \mathrm{mg} / \mathrm{L})$ significantly decreased total carotenoid contents in $H$. physodes when compared to unexposed sample $(\mathrm{P}<0.05)$. The maximum change in total carotenoid content was observed as $0.056 \mathrm{mg} \mathrm{g}^{-1}$ after $18 \mathrm{~h} 120 \mathrm{mg} / \mathrm{L} \mathrm{Cd}^{+2}$ treatment in H. physodes $(\mathrm{P}<0.05)$.

\section{Effect of $U V$ radiations on total carotenoid content}

Total carotenoid content of lichen specimen was founded a decrease expose to all UV radiations when compared to the control sample. The maximum change in total carotenoid contents was determined after $12 \mathrm{j} / \mathrm{cm}^{2}$ expose to UV radiations $(P<0.05)$. The highest decrease after $12 \mathrm{j} / \mathrm{cm}^{2}$ treatment was observed after UVA + UVB radiations exposure $\left(0.070 \mathrm{mg} \mathrm{g}^{-1}\right)$ in $H$. physodes $(\mathrm{P}<0.05)$.

\section{Determination of heavy metals and $U V$ radiations on RAPD profiles in Hypogymnia physodes}

A representative example of the results obtained by RAPD analysis is shown in Figure 3. The concentrations measured for the DNA samples were approximately in the range of 1285-2012 $\mathrm{ng} / \mu \mathrm{l}$ for all heavy metals and 964-2077 $\mathrm{ng} / \mu \mathrm{l}$ for all UV radiations exposures at $260 \mathrm{~nm} / 280 \mathrm{~nm}$ ratios between 1.64-1.97 and 1.54-1.99, respectively.

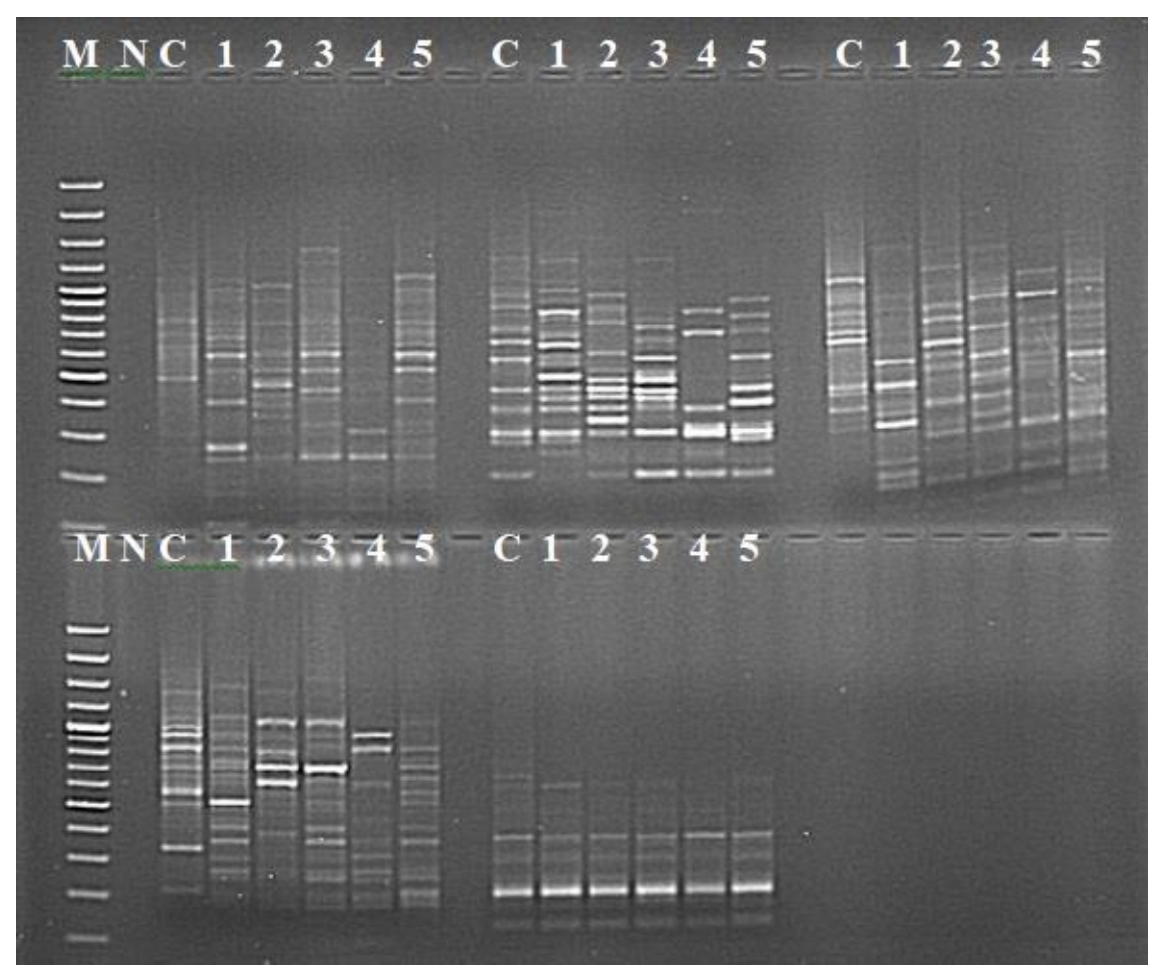

Figure 3. The results of RAPD-PCR treating at UVB radiation in Hypogymnia physodes (topleft OPCO2, top-center OPC04; top-right TubeA05, lower-left OPC07, lower-center OPC10 
primers). (M: Marker; $N$ : Negative control; C: Control sample (non-stressed sample); 1: $\left.4 \mathrm{j} / \mathrm{cm}^{2} ; 2: 8 \mathrm{j} / \mathrm{cm}^{2} ; 3: 12 \mathrm{j} / \mathrm{cm}^{2} ; 4: 20 \mathrm{j} / \mathrm{cm}^{2} ; 5: 40 \mathrm{j} / \mathrm{cm}^{2}\right)$

In RAPD analyses, some of the primers displayed significant differences in band patterns formed by loss of normal bands and appearance of new bands in the treated heavy metals and UV radiation exposure in comparison to the untreated sample profiles. The highest number of appearance and disappearance of new bands was observed at $30 \mathrm{mg} / \mathrm{L} \mathrm{Cd^{+2 }}$ concentrations with ten primers. Most of the new band appearances/disappearances were shown in $\mathrm{Cd}^{+2}$ contaminations (33 bands) observed in $30 \mathrm{mg} / \mathrm{L} \mathrm{Cd}{ }^{+2}$ contaminations. The lowest band appearances/disappearances were determined in $\mathrm{Cd}^{+2}$ ( 8 bands) and $\mathrm{Pb}^{+2}$ ( 8 bands) exposure to $30 \mathrm{~min}$. The highest band appearances/disappearances in different UV radiation exposures were shown at $40 \mathrm{j} / \mathrm{cm}^{2}$ exposure (42 bands).

As an analysis of the samples applied $\mathrm{Cd}^{+2}$ heavy metal in $H$. physodes, the highest genomic template stability (GTS\%) value occurred after exposure to $\mathrm{Cd}^{+2}$ heavy metal stress at $72 \mathrm{~h}$ in all concentrations (30, 60 and $120 \mathrm{mg} / \mathrm{L}) .30,60$ and $120 \mathrm{mg} / \mathrm{L} \mathrm{Cd}^{+2}$ treatment resulted in the highest GTS value of $91.1 \%, 85.5 \%$ and $86.6 \%$, respectively. The lowest GTS value occurred after exposure to $\mathrm{Cd}^{+2}$ at $2 \mathrm{~h}$ in all concentrations. The lowest GTS value $(63.3 \%, 64.4 \%$ and $70.0 \%)$ was obtained in the 30,60 and $120 \mathrm{mg} / \mathrm{L}$ $\mathrm{Cd}^{+2}$ heavy metal treatment, respectively. According to this, the highest and lowest band variations were observed at 30,60 and $120 \mathrm{mg} / \mathrm{L} \mathrm{Cd}^{+2}$ concentrations at $2 \mathrm{~h}$ and $72 \mathrm{~h}$, respectively. In terms of $\mathrm{Cr}^{+6}$ stress in $H$. physodes lichen specimen, the highest and the lowest GTS values were detected at $48 \mathrm{~h}$ of $30 \mathrm{mg} / \mathrm{L}(88.5 \%)$ and $72 \mathrm{~h}$ of $60 \mathrm{mg} / \mathrm{L}$ $(90.6 \%)$ and $72 \mathrm{~h}$ of $120 \mathrm{mg} / \mathrm{L}(90.6 \%)$, respectively. The lowest GTS value was obtained at $30 \mathrm{~min}$ and $18 \mathrm{~h}$ in the $30 \mathrm{mg} / \mathrm{L} \mathrm{Cr}^{+6}(69.7 \%), 2 \mathrm{~h}$ in the $60 \mathrm{mg} / \mathrm{L} \mathrm{Cr}^{+6}(70.8 \%)$ and $1 \mathrm{~h}$ in $120 \mathrm{mg} / \mathrm{L} \mathrm{Cr}{ }^{+6}(78.1 \%)$. In terms of $\mathrm{Pb}^{+2}$ stresses in $H$. physodes, the highest GTS value was observed after exposure to $\mathrm{Pb}^{+2}$ at $72 \mathrm{~h}$ in all concentrations. 30, 60 and 120 $\mathrm{mg} / \mathrm{L} \mathrm{Pb}^{+2}$ treatments resulted in the highest GTS values of $93.0 \%, 93.0 \%$ and $91.3 \%$, respectively. The lowest GTS values were obtained at $30 \mathrm{~min}, 2 \mathrm{~h}$ and $6 \mathrm{~h}$ in $30 \mathrm{mg} / \mathrm{L}$ (82.6\%), $30 \mathrm{~min}$ at $60 \mathrm{mg} / \mathrm{L}(78.2 \%)$ and $30 \mathrm{~min}$ at $120 \mathrm{mg} / \mathrm{L}(80.8 \%) \mathrm{Pb}^{+2}$ treatments.

In terms of UVA radiation stress in $H$. physodes lichen specimen, the highest GTS value $(87.8 \%)$ was observed after exposure to $4 \mathrm{j} / \mathrm{cm}^{2}$ UVA radiation. The lowest GTS value $(76.5 \%)$ was obtained at $40 \mathrm{j} / \mathrm{cm}^{2}$ UVA radiation. As regards UVA and daylight stress in $H$. physodes, the highest GTS value $(88.6 \%)$ was observed after exposure to $4 \mathrm{j} / \mathrm{cm}^{2}$ UVA and daylight radiations. The lowest GTS value $(80.86 \%)$ was obtained at $12 \mathrm{j} / \mathrm{cm}^{2}$ UVA and daylight radiations. Despite UVC stress in $H$. physodes, the highest GTS value (92.1\%) was observed exposed to $4 \mathrm{j} / \mathrm{cm}^{2} \mathrm{UVC}$ radiation and the lowest GTS value $(76.5 \%)$ was determined at $40 \mathrm{j} / \mathrm{cm}^{2} \mathrm{UVC}$ radiation. In terms of daylight stress in $H$. physodes, the highest GTS value $(89.67 \%)$ was realized exposed to $8 \mathrm{j} / \mathrm{cm}^{2}$ daylight radiation but the lowest GTS value $(84.78 \%)$ was obtained at $40 \mathrm{j} / \mathrm{cm}^{2}$ daylight radiation.

When all UV radiations and UVB exposure were compared, maximum changes of UV exposure were determined in UVB radiation in $H$. physodes. The significant changes were determined, such as appearances of some new bands or the disappearance of bands when compared to the control. A maximum of 28 bands disappeared among the exposed $H$. physodes with $40 \mathrm{j} / \mathrm{cm}^{2}$, while in $20 \mathrm{j} / \mathrm{cm}^{2}$, a maximum of 13 new bands appeared in $H$. physodes exposed to UVB radiation (Table 4). Also, the results showing the most variation among the different heavy metal $\left(\mathrm{Cd}^{+2}, \mathrm{Cr}^{+6}, \mathrm{~Pb}^{+2}\right)$ and time arrival 
$(0.5,1,2,6,18,24,48$ and $72 \mathrm{~h})$ combinations applied to the $H$. physodes lichen species are given in Table 5. H. physodes lichen specimen for three different UV treatments were applied (UVA, UVB, UVC, UVD, UVA + UVB, UVA + UVD) in five different doses $\left(4,8,12,20\right.$ and $\left.40 \mathrm{j} / \mathrm{cm}^{2}\right)$. The results showing the most variation among the UV radiations and doses combinations applied to the $H$. physodes lichen species are given in Table 6. The highest GTS value $(88.4 \%)$ was observed exposed to $4 \mathrm{j} / \mathrm{cm}^{2}$ UVB radiation (Table 7). The lowest GTS value (73.18\%) was obtained at $40 \mathrm{j} / \mathrm{cm}^{2} \mathrm{UVB}$ radiation (Table 7). Regarding UVA and UVB stress in $H$. physodes, the highest GTS value $(84.3 \%)$ was observed exposed to $4 \mathrm{j} / \mathrm{cm}^{2}$ UVA and UVB radiations. The lowest GTS value (63.4\%) was obtained at $40 \mathrm{j} / \mathrm{cm}^{2}$ UVA and UVB radiations.

Table 4. Varying band-number using OPC01, OPC02, OPC04, OPC07, OPC10 and TubeA05 primers as a result of UVB radiation samples in Hypogymnia physodes

\begin{tabular}{|c|c|c|c|c|c|c|c|c|c|c|c|}
\hline \multirow[t]{2}{*}{ Primers } & \multirow[t]{2}{*}{$\mathrm{C}$} & \multicolumn{2}{|c|}{4 j UVB } & \multicolumn{2}{|c|}{8 j UVB } & \multicolumn{2}{|c|}{12 j UVB } & \multicolumn{2}{|c|}{20 j UVB } & \multicolumn{2}{|c|}{40 j UVB } \\
\hline & & $\mathbf{a}$ & $\mathbf{b}$ & $\mathbf{a}$ & $\mathbf{b}$ & $\mathbf{a}$ & b & $\mathbf{a}$ & $\mathbf{b}$ & $\mathbf{a}$ & $\mathbf{b}$ \\
\hline OPC 01 & 23 & 1 & 3 & 1 & 1 & 0 & 3 & 2 & 4 & 2 & 4 \\
\hline OPC 02 & 23 & 2 & 0 & 3 & 2 & 4 & 2 & 3 & 3 & 1 & 3 \\
\hline OPC 04 & 23 & 0 & 0 & 0 & 2 & 0 & 3 & 4 & 3 & 3 & 7 \\
\hline OPC 07 & 23 & 1 & 4 & 2 & 3 & 1 & 3 & 1 & 7 & 0 & 4 \\
\hline OPC 10 & 23 & 2 & 0 & 1 & 2 & 2 & 2 & 1 & 2 & 2 & 6 \\
\hline Tube A05 & 23 & 0 & 3 & 0 & 1 & 2 & 4 & 2 & 0 & 1 & 4 \\
\hline \multicolumn{2}{|l|}{138} & 6 & 10 & 7 & 11 & 9 & 17 & 13 & 19 & 9 & 28 \\
\hline \multicolumn{2}{|l|}{$a+b$} & \multicolumn{2}{|c|}{16} & \multicolumn{2}{|c|}{18} & \multicolumn{2}{|c|}{26} & \multicolumn{2}{|c|}{32} & \multicolumn{2}{|c|}{37} \\
\hline
\end{tabular}

$\mathrm{a}+\mathrm{b}=$ The total number of band alternations, $\mathrm{C}=$ control sample $=$ non-stressed sample

Table 5. H. physodes lichen specimen for three different metal stress treatments were applied $\left(\mathrm{Pb}^{+2}, \mathrm{Cd}^{+2}\right.$, and $\left.\mathrm{Cr}^{+6}\right)$ in three different doses $(30,60$ and $120 \mathrm{mg} / \mathrm{L})$ for eight different periods $(0.5,1,2,6,18,24,48$ and $72 \mathrm{~h})$. The results showing the most variation among the different heavy metal $\left(\mathrm{Cd}^{+2}, \mathrm{Cr}^{+6}, \mathrm{~Pb}^{+2}\right)$ and time arrival $(0.5,1,2,6,18,24,48$ and $72 \mathrm{~h}$ ) combinations applied to the $H$. physodes lichen species are given

\begin{tabular}{|c|c|c|c|c|c|c|c|c|c|c|c|c|c|c|c|c|c|c|c|}
\hline \multirow[b]{2}{*}{ Primers } & \multicolumn{2}{|c|}{$\begin{array}{c}30 \mathrm{ppm}^{+} \\
\mathrm{Cd}^{+2}\end{array}$} & \multicolumn{2}{|c|}{$\begin{array}{c}60 \mathrm{ppm}^{+} \\
\mathbf{C d}^{+2}\end{array}$} & \multicolumn{2}{|c|}{$\begin{array}{c}120 \mathrm{ppm} \\
\mathrm{Cd}^{+2}\end{array}$} & \multicolumn{2}{|c|}{$\begin{array}{c}30 \mathrm{ppm}^{\mathrm{Cm}} \\
\mathrm{Cr}^{+6}\end{array}$} & \multicolumn{2}{|c|}{$\begin{array}{c}\text { 60 ppm } \\
\mathrm{Cr}^{+6}\end{array}$} & \multicolumn{2}{|c|}{$\begin{array}{c}120 \mathrm{ppm} \\
\mathrm{Cr}^{+6}\end{array}$} & \multicolumn{2}{|c|}{$\begin{array}{c}30 \text { ppm } \\
\mathbf{P b}^{+2}\end{array}$} & \multicolumn{2}{|c|}{$\begin{array}{c}60 \mathrm{ppm} \\
\mathrm{Pb}^{+2}\end{array}$} & \multicolumn{2}{|c|}{$\begin{array}{c}120 \text { ppm } \\
\mathrm{Pb}^{+2}\end{array}$} & \multirow{2}{*}{$\mathbf{T}$} \\
\hline & TB & $\begin{array}{l}a+b \\
(2 h)\end{array}$ & TB & $\begin{array}{l}a+b \\
(2 \mathrm{~h})\end{array}$ & TB & $\begin{array}{l}a+b \\
(2 h)\end{array}$ & TB & $\begin{array}{l}a+b \\
(6 h)\end{array}$ & TB & $\begin{array}{l}a+b \\
(2 h)\end{array}$ & TB & $\left.\begin{array}{l}a+b \\
(1\end{array}\right)$ & TB & $\begin{array}{c}\mathbf{a}+\mathbf{b} \\
(30 \\
\text { min) }\end{array}$ & TB & $\begin{array}{c}\mathbf{a}+\mathbf{b} \\
(\mathbf{3 0} \\
\mathbf{m i n})\end{array}$ & TB & $\begin{array}{c}\mathbf{a}+\mathbf{b} \\
(\mathbf{3 0} \\
\min )\end{array}$ & \\
\hline $\begin{array}{c}\text { OPC } 01 \\
\text { OPC } 02 \\
\text { OPC } 04 \\
\text { OPC } 07 \\
\text { OPC } 10 \\
\text { TubeA05 }\end{array}$ & 90 & 33 & 90 & 32 & 90 & 27 & 96 & 30 & 96 & 28 & 96 & 21 & 115 & 20 & 115 & 25 & 115 & 22 & RAPD \\
\hline $\begin{array}{l}\text { Methylation } \\
\text { types (MT) }\end{array}$ & TB & \begin{tabular}{|l|}
$\mathbf{a}+\mathbf{b}$ \\
MTII \\
\end{tabular} & TB & \begin{tabular}{|c|}
$\mathbf{a}+\mathbf{b}$ \\
MTII
\end{tabular} & TB & $\begin{array}{l}\text { a+b } \\
\text { MTI }\end{array}$ & TB & $\mathbf{a}+\mathbf{b}$ & TB & \begin{tabular}{|c|} 
a+b \\
MTII
\end{tabular} & TB & $\mathbf{a}+\mathbf{b}$ & TB & $\mathbf{a}+\mathbf{b}$ & TB & \begin{tabular}{|c|}
$\mathbf{a}+\mathbf{b}$ \\
MTII \\
\end{tabular} & TB & $\mathbf{a}+\mathbf{b}$ & \\
\hline $\begin{array}{c}\text { Type I } \\
\text { Type II } \\
\text { Type III } \\
\text { Type IV }\end{array}$ & 413 & 213 & 413 & 314 & 413 & 351 & 357 & 81 & 357 & 87 & 357 & 98 & 456 & 127 & 456 & 149 & 456 & 181 & $\begin{array}{l}\text { MSAP- } \\
\text { AFLP }\end{array}$ \\
\hline
\end{tabular}

$\mathrm{a}+\mathrm{b}=$ The total number of band alternations, $\mathrm{TB}=$ Total band (non-stressed sample $=$ control sample), $\mathrm{T}=\mathrm{Technic}$, MT = Methylation types 


\section{Methylation DNA and polymorphism in examined lichen specimen to different levels of stress condition}

Band alterations in heavy metals and UV radiations exposure were compared with respect to the untreated control samples. 413 to 691 bands were produced in the untreated sample, and 217 bands with an average of 11 per primer were obtained in the MSAP-AFLP analysis. The total number of band alterations $(\mathrm{a}+\mathrm{b})$ was 117 bands for the $\mathrm{Cd}^{+2}$ heavy metal and lichen specimen stressed with UVB (Fig. 4).

Table 6. H. physodes lichen specimen for three different UV treatments were applied (UVA, $U V B, U V C, U V D, U V A+U V B, U V A+U V D)$ in five different doses $(4,8,12,20$ and 40 $\left.j / \mathrm{cm}^{2}\right)$. The results showing the most variation among the $U V$ radiation and dose combinations applied to the $H$. physodes lichen species are given

\begin{tabular}{|c|c|c|c|c|c|c|c|c|c|c|c|c|c|}
\hline \multirow[b]{2}{*}{ Primers } & \multicolumn{2}{|c|}{ UVA } & \multicolumn{2}{|c|}{ UVB } & \multicolumn{2}{|c|}{ UVC } & \multicolumn{2}{|c|}{ UVD } & \multicolumn{2}{|c|}{ UVA+UVB } & \multicolumn{2}{|c|}{ UVA+UVD } & \multirow{2}{*}{$\mathbf{T}$} \\
\hline & TB & $\begin{array}{c}a+b \\
(40 \mathrm{~J}) \\
\end{array}$ & TB & $\begin{array}{c}a+b \\
(40 \mathrm{~J})\end{array}$ & TB & \begin{tabular}{|c|}
$a+b$ \\
$(40 \mathrm{~J})$
\end{tabular} & TB & $\begin{array}{c}a+b \\
(40 J)\end{array}$ & TB & $\begin{array}{c}a+b \\
(40 \mathrm{~J})\end{array}$ & TB & $\begin{array}{c}a+b \\
(12 J)\end{array}$ & \\
\hline $\begin{array}{c}\text { OPC } 01 \\
\text { OPC } 02 \\
\text { OPC } 04 \\
\text { OPC } 07 \\
\text { OPC } 10 \\
\text { Tube A05 } \\
\end{array}$ & 115 & 27 & 138 & 37 & 115 & 27 & 115 & 28 & 115 & 42 & 115 & 22 & RAPD \\
\hline $\begin{array}{c}\text { Methylation } \\
\text { types }\end{array}$ & TB & \begin{tabular}{|c|}
$\mathbf{a}+\mathbf{b}$ \\
MTII
\end{tabular} & TB & $\begin{array}{c}\mathbf{a + b} \\
\text { MTII }\end{array}$ & TB & $\begin{array}{c}\mathbf{a}+\mathbf{b} \\
\text { MTI }\end{array}$ & TB & $\mathbf{a + b}$ & TB & $\begin{array}{c}\mathbf{a}+\mathbf{b} \\
\text { MTII }\end{array}$ & TB & $\mathbf{a}+\mathbf{b}$ & \\
\hline $\begin{array}{c}\text { Type I } \\
\text { Type II } \\
\text { Type III } \\
\text { Type IV }\end{array}$ & 691 & 117 & 691 & 451 & 691 & 141 & 691 & 92 & 691 & 381 & 691 & 204 & $\begin{array}{l}\text { MSAP- } \\
\text { AFLP }\end{array}$ \\
\hline
\end{tabular}

$\mathrm{a}+\mathrm{b}=$ The total number of band alternations, $\mathrm{TB}=$ Total band (non-stressed sample $=$ control sample), $\mathrm{T}=$ Technic, $\mathrm{MT}=$ Methylation types

Table 7. The rates of GTS values using UVB radiation in Hypogymnia physodes lichen specimen

\begin{tabular}{c|c}
\hline Samples-UVB & Rates of GTS (\%) \\
\hline $4 \mathrm{j} / \mathrm{cm}^{2}$ & 88.40 \\
$8 \mathrm{j} / \mathrm{cm}^{2}$ & 86.95 \\
$12 \mathrm{j} / \mathrm{cm}^{2}$ & 81.15 \\
$20 \mathrm{j} / \mathrm{cm}^{2}$ & 76.81 \\
$40 \mathrm{j} / \mathrm{cm}^{2}$ & 73.18 \\
\hline
\end{tabular}

The highest rate of methylation was obtained with Type-2 primer (28.9\%) and Type$3(59.3 \%)$ primers in the $\mathrm{Cd}^{+2}$ heavy metal (Table 5) and $H$. physodes lichen specimen stressed with UVB radiation (Table 6). The highest rate of changes was observed in the $H$. physodes exposed to heavy metal stress for $6 \mathrm{~h}$ and UVB radiation stress for 12 and 
$24 \mathrm{~h}$. When the results of the MSAP - AFLP analysis were evaluated based on the methylation types in the heavy metal stressed samples, the maximum level of methylation (33.3\%) was observed in Type II, and the lowest level of methylation (63.3\%) was seen in Type III. Type II methylation was not observed for the first $6 \mathrm{~h}$ and then, occurred at a rate of $34.3 \%$ at $12 \mathrm{~h}$ and $24 \mathrm{~h}$. The rate of Type II methylation $(34.3 \%)$ remained the same until the end of $12 \mathrm{~h}$ and completely disappeared at $24 \mathrm{~h}$ in $\mathrm{Cr}^{+6}$ heavy metal exposure in $H$. physodes.

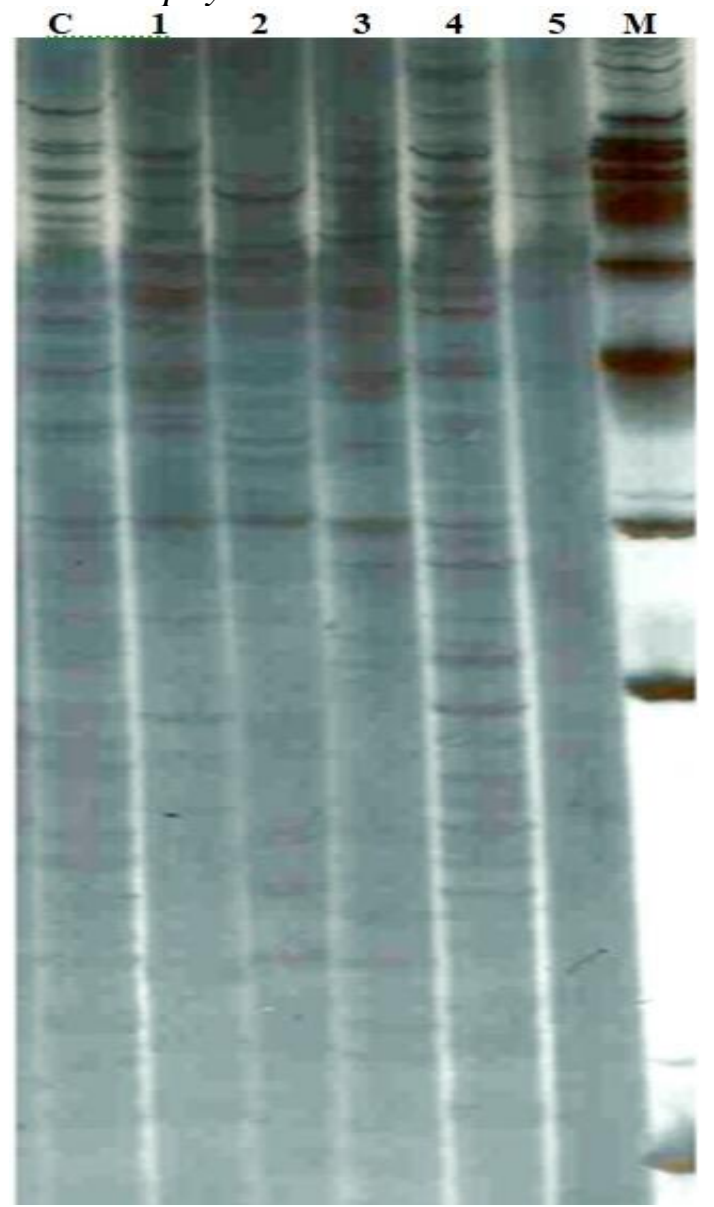

Figure 4. AFLP profiles generated by Type II metilation from Hypogymnia physodes exposed to UVB radiation. (C: Control sample (non-stressed sample); $1: 4 \mathrm{j} / \mathrm{cm}^{2} ; 2: 8 \mathrm{j} / \mathrm{cm}^{2} ; 3: 12 \mathrm{j} / \mathrm{cm}^{2} ; 4$ : $20 \mathrm{j} / \mathrm{cm}^{2} ; 5: 40 \mathrm{j} / \mathrm{cm}^{2} ;$ M: Marker)

\section{Discussion}

In our study were applied increasing $\mathrm{Cr}^{+6}, \mathrm{~Pb}^{+2}$ and $\mathrm{Cd}^{+2}$ heavy metal concentrations and UV radiations in different doses in $H$. physodes lichen specimen. Heavy metal accumulation capacities, total protein content and chlorophyll parameters constituted against stress were determined in lichen specimen. In addition, the genotoxic effect generated by heavy metals and UV radiations was investigated with RAPD and MSAP AFLP techniques at a molecular level (Fig. 1). This is the first evaluation of the changes in DNA methylation and polymorphism in methylated DNA in lichen specimen under heavy metals and UV radiations stress.

Gill et al. (2015) have shown that the toxic effects of $\mathrm{Cr}^{+6}$ heavy metal are observed in four different cultivars of Brassica napus L. The study determined plant growth and 
biomass ratio changed to exposure to $\mathrm{Cr}^{+6}$ concentrations. After $\mathrm{Cr}^{+6}$ application, the effect of Malondialdehyde (MDA) and Reactive oxygen species (ROS) increased, which could be an indication of cell damage in the plant. According to the results of our study also found that $H$. physodes lichen specimen was more accumulate in $\mathrm{Cd}^{+2}$ and $\mathrm{Cr}^{+6}$ heavy metals when compared to $\mathrm{Pb}^{+2}(\mathrm{P}<0.05)$. In our study, the damage caused by heavy metal application to lichen specimen may be due to the effects of ROS and MDA.

In another study, Fernandez et al. (1992) have indicated that fly ash, tending to be close to the source, is normally associated with the coarse fraction. This study has reported more storage $\mathrm{Cr}$ capacity of the samples collected around $5 \mathrm{~km}$ from the ironsteel factory. They have also stated that particularly $H$. physodes and Evernia prunastri have similar $\mathrm{Cr}$ accumulation ratio. Aslan et al. (2006) have reported that H. physodes shows high levels of $\mathrm{Ca}, \mathrm{Ti}, \mathrm{Fe}$ and $\mathrm{Ba}$ heavy metal accumulation collected from Ordu, province of Turkey. In our study results revealed that $H$. physodes lichen specimen showed to accumulate all heavy metals at a significant level $(\mathrm{P}<0.05)$. Koroleva and Revunkov (2017) investigated to create a database of trace elements concentrations in the sample of the epiphytic lichen Hypogymnia physodes and to identify the spatial patterns of iron, manganese, nickel, cadmium, silver, lead, strontium, rubidium, and calcium in the Kaliningrad region. They stated that the lichen specimen accumulates microelements more intensively in the west of the Kaliningrad region than in its continental part, which is also due not only to a higher level of urbanization of the territory but also to the region's climatic features. Zulaini et al. (2019) investigated the accumulation of heavy metals on two types of epiphytic lichens, Parmotrema tinctorum and Usnea diffracta. They stated that $P$. tinctorum can be positively compared to $U$. diffracta for identifying the levels of heavy metals, due to the higher capability to accumulate heavy metals without affecting the internal structure. These lichen species positively responded to the heavy metal accumulation levels. Branquinho et al. (1997) have shown that they were able to determine and quantify the cellular location of $\mathrm{Cu}$ in lichens. They have been expected to regulate the extracellular uptake, time or concentration from conventional kinetic studies with other organisms and heavy metals. Usnea sp. were most sensitive to $\mathrm{Cu}$ uptake compare with other lichen species, since physiological changes occurred for lower supplied $\mathrm{Cu}$ concentrations than $R$. fastigiata. It seems that lichen specimen can accumulate much more metal elements than it needs and that accumulation is capable of high tolerance in our study. Thanks to these properties, lichens are defined as the best monitor-indicator organisms that can be used to display atmospheric heavy metal pollution (Abas et al., 2019; Benitez et al., 2019; Ramic et al., 2019). Li et al. (2009) have demonstrated comparative effects of $\mathrm{Cd}^{+2}$ and $\mathrm{Pb}^{+2}$ on biochemical response and DNA damage in the earthworm Eisenia fetida (Annelida, Oligochaeta). The evaluation of DNA damage in earthworms used the comet assay. As a result, it was the aim of the study to determine more detailed information on the effects of heavy metals on earthworms' organisms. When the results of our study and that of Liu et al.'s are compared, both studies clearly show that both of the examined biological organisms were affected by all heavy metal treatments. This study determined that selecting lichen specimen was important for accumulating heavy metals. As a result of this study, $H$. physodes lichen specimen could serve as biomarkers for environmental pollution. It can be used to a novel organism as an environmentally friendly and cost-effective technology for remediation of polluted sites. 
Doğan and Saygideğer (2009) have investigated some morphological and physiological changes in Ceratophyllum demersum L. at different concentrations of $\mathrm{Cd}^{+2}(0,0.01,0.1$ and $1 \mathrm{ml} / \mathrm{L})$ effect in $96 \mathrm{~h}$. They have stated that total soluble sugar and protein content are reduced by the application of $\mathrm{Cd}^{+2}$. Although the amount of protein showed a decrease when compared to the controls, there was no significant correlation between protein content and heavy metals. The reason for the decrease in protein content in plants is often caused by the inhibition of protein synthesis or proteolysis triggered by ROS produced by oxidative stress. Duman et al. (2010) have investigated the biological response against $\mathrm{Cr}^{+6}$ heavy metal in Ceratophyllum demersum L. $\mathrm{Cr}$ accumulation, plant growth, lipid peroxidation, ion escape, photosynthetic pigmentation, protein and proline content have been investigated depending on concentration changes. They have stated a statistically significant difference between $1 \mathrm{mM} \mathrm{Cr}^{+6}$ treatment and 5-10 $\mathrm{mM} \mathrm{Cr}^{+6}$ treatments. In our study, the decrease in total protein in lichen specimen was observed when compared with 60 and $120 \mathrm{mg} / \mathrm{L} \mathrm{Pb}^{+2}, \mathrm{Cr}^{+6}$ and $\mathrm{Cd}^{+2}$ heavy metals $(\mathrm{p}<0.05)$. Particularly, $\mathrm{Cd}^{+2}$ and $\mathrm{Cr}^{+6}$ heavy metals constitute a high level of damage to protein content when compared with other examined parameters in $H$. physodes $(\mathrm{p}<0.05)$. In brief, the amount of protein in lichen specimen decreased at a statistically significant level after all heavy metals application $(\mathrm{P}<0.05)$. Our study results revealed that the respond of heavy metal stress was similar to the protein content of other study results. We evaluated the change in the protein content of $H$. physodes lichen sample exposure to UV stress. Our study results also demonstrated that total protein content in $H$. physodes lichen specimen applied with UV radiations showed an opposite relation with all samples. Reduction in total protein content was observed depending on the application dose of UVA, UVB, UVC, daylight, UVA + daylight, and UVA + UVB radiations when compared to the unexposed sample. A decrease in protein content of lichen specimen was determined up to $12 \mathrm{j} \mathrm{UV}$ dose, but further UV doses were not detected changes of protein content in lichen specimen. For this reason, lichen specimen may have a certain level of tolerance. It is very important to evaluate the protein relationship with the response given to stress conditions. Protein molecules play a significant role in the determination of mainly heavy metal stress and UV radiations exposure. If further protein-related works like proteome studies it may be used in a biomarker for environmental pollution.

A study conducted has shown the physiological change generated at a cellular extent as a result of the exposure of Cladonia arbuscular and Peltigera rufescens lichen species to mercury (Hg) (Pisani et al., 2011). The results of this study have put forward that photosynthetic pigments are sensitive to $\mathrm{HgCl}_{2}$ in both species. Chl-a, -b, and carotenoids content significantly decreased in C. arbuscula subsp. mitis but only Chl-a and carotenoids significantly decreased in P. rufescens (Pisani et al., 2011). Chettri et al. (1998) were hypothesized that $\mathrm{Cu}$ was responsible for the reduced chlorophyll content of lichens growing in mining areas in which $\mathrm{Cu}, \mathrm{Zn}$, and $\mathrm{Pb}$ were present in the soil. Therefore, they were examined the effect of $\mathrm{Cu}, \mathrm{Zn}$, and $\mathrm{Pb}$, individually and in combination, on the respective thallus metal content of the lichens $C$. convoluta and $C$. rangiformis, and the subsequent effect on chlorophyll content. They found that increasing lichen $\mathrm{Cu}$ content [up to $1600 \mu \mathrm{g} \mathrm{g}^{-1}$ dry weight (DW)] had no effect on the total chlorophyll content of $C$. rangiformis, whereas $\mathrm{Cu}$ concentrations exceeding $175 \mu \mathrm{g} \mathrm{g}^{-1} \mathrm{DW}$ caused a decrease in total chlorophyll content in $C$. convoluta, which was $40 \%$ at $1560 \mu \mathrm{g} \mathrm{Cu} \mathrm{g}^{-1} \mathrm{DW}$. As a result, the $\mathrm{Cu}$ effects on chlorophyll were reduced in the presence of $\mathrm{Pb}$ and $\mathrm{Zn}$ in both lichens, but to a lesser extent in $C$. rangiformis. 
Metal cations appeared to be ionically bound within the cell wall in an exchangeable form with binding affinities of $\mathrm{Pb}>\mathrm{Cu}>\mathrm{Zn}$. Similarly, Karakoti et al. (2014) found that $\mathrm{Pb}, \mathrm{Cu}, \mathrm{Fe}$, and $\mathrm{Cr}$ have little effect on chlorophyll degradation in lichen Pyxine cocoes. Monnet et al. (2001) have observed an increase of chl-a content after applied with $10 \mathrm{mg} / \mathrm{L}$ heavy metal stress for 8 days, but then the content of chl-a decreased in ryegrass (Lolium perenne). Casano et al. (2015) reported that the proportion of cell walls is important for the capacity to immobilize extracellular $\mathrm{Pb}^{+2}$ from the photobiont layer. Therefore, the external cell wall could help to decrease the deleterious effects of $\mathrm{Pb}$ on chlorophyll content in a short time $(24 \mathrm{~h})$ exposure. Gurbanov and Unal (2018) revealed that $\mathrm{Pb}^{+2}$ exposure diminished the total nucleic acid quantity, which could be an important parameter for the elucidation of heavy metal tolerance mechanisms in lichens. Similarly, we observed that the contents of chl-a, chl-b and total chl in $H$. physodes were highest decreased after applied with $30 \mathrm{mg} / \mathrm{L} \mathrm{Cr}^{+6}, \mathrm{~Pb}^{+2}$ and $\mathrm{Cd}^{+2}$ heavy metal concentration $(\mathrm{P}<0.05)$. The contents of the same parameters in $H$. physodes were also significantly decreased after applied with all other 60 and $120 \mathrm{mg} / \mathrm{L} \mathrm{Pb}^{+2}$ and $\mathrm{Cd}^{+2}$ concentrations $(\mathrm{P}<0.05)$. Spectrophotometric measures were conducted to determine the carotenoid amount in $H$. physodes applied different heavy metal concentrations and UV radiations. There was a significant decrease in carotenoid amounts after exposed to $8 \mathrm{j} / \mathrm{cm}^{2}$ all UV radiations in $H$. physodes $(\mathrm{P}<0.05)$. In this study, we found that the application of heavy metals and UV exposure prevents loss of chlorophyll and carotenoid. UVA and UVB radiations together have more harmful effects, although $H$. pyhsodes may have shown quite a tolerance. Similarly, H. pyhsodes have been deposited at higher rate heavy metals.

Chettri et al. (1998) have indicated that the ratio of chlorophyll $\mathrm{a} / \mathrm{b}$ is more sensitive to changes in the content of the lichen. They determined a marked decrease in the ratio of chlorophyll a/b, from 3.0 to 0.4 for $C$. convoluta and from 3.2 to 0.8 for $C$. rangiformis, occurred when the thallus $\mathrm{Cu}$ content exceeded 175 and $200 \mathrm{mg} \mathrm{g}^{-1} \mathrm{DW}$, respectively. Similarly, we found that there is a significant decrease with increasing treatments the ratio of chlorophyll a/b content in $H$. physodes. Larsson et al (2009) reported that the ratio of chlorophyll $\mathrm{a} / \mathrm{b}$ ratio increased with increasing UVB radiation in Xantoria aureola lichen species at $21{ }^{\circ} \mathrm{C}$ degrees. We also found that after $4 \mathrm{j} / \mathrm{cm}^{2}$ treatments, the ratio of chlorophyll $\mathrm{a} / \mathrm{b}$ increase with increasing UVB radiation.

Heavy metal and UV stress toxicity have been extensively described in physiological, cellular and molecular biological aspects in the literature. The development of several PCR based techniques provides many advantages in the analysis of genetic toxicology. PCR based technique is simple, fast and capable of detecting point mutations and also a temporary alteration of DNA. Many studies have displayed that molecular technique may potentially form to detect DNA damage and mutational events in cells of different organisms. Genotoxic pollutants in the environment continue to grow rapidly, thereby stressing the need for rapid monitoring of genotoxicity in lichen species. Lichens can be used for this purpose due to the best biomonitor organism. The RAPD band profile generated after exposure to $\mathrm{Cr}^{+6}, \mathrm{Cd}^{+2}$ and $\mathrm{Pb}^{+2}$ heavy metals in the lichen specimen was determined with the RAPD profile of the controls, differences of band number were detected. Cansaran-Duman et al. (2011) have determined the genotoxic contamination in the Evernia prunastri lichen species with the RAPD analyses. Körpe-Aksoy and Aras (2010) have studied eggplant seeds in a controlled setting applied to $\mathrm{Cu}^{+2}$ metal stress in different concentrations. The results showed that the changes in the GTS rates of the seeds that developed in different $\mathrm{Cu}^{+2}$ 
concentrations could be determined by generating RAPD profiles. This study significantly determined the maximum change of band intensities. The highest number of bands that appeared and disappeared was observed in the H. physodes lichen sample for UVB exposure. Especially, different changes in GTS rates (\%) were shown in lichen specimen. Monitoring of various environmental stresses induced genotoxic effect directly on genomic DNA by RAPD analysis is mainly associated with unexposed sample and lichen treated with different stresses conditions. The changes in physiological and biochemical parameters such as shoot-root length, photosynthetic pigment contents, and antioxidative enzyme level support genomic template stability (Atienzar et al., 1999).

DNA methylation has been shown as a significant indicator of epigenetic and mutagenic effects and it causes differential gene expression, cell differentiation, chromatin inactivation and carcinogenesis in eukaryotic organisms ( $\mathrm{Xu}$ et al., 2000; Mastan et al., 2012). The epigenetic organization of plant development can be used in production as much as an adaptation to stress since gene expression can be affected by the structure of the chromatin related to the epigenetic organization (Mirouze and Paszkowski, 2011). The level of the presence of methylcytosine can be determined with multiple approaches in many terms since there is a very appropriate technique to determine the methylation rate in the genome (Rein et al., 1997). MSAP-AFLP is a very potent technique to study the genome methylation status. The use of MSAP-AFLP assay has been useful in the detection of the tolerance level toward different environmental stresses. Therefore, biochemical and physiological assays are not enough to obtain deeper insight into the lichen stress response to biotic or abiotic stresses. In the present study, assessment of changes in DNA methylation by MSAP-AFLP in lichen specimen subjected to heavy metals and UV exposures. $H$. physodes thallus $69 \%$ methylation was determined in heavy metal stress. Similarly, 58\% polymorphism was showed in methylated DNA from $H$. physodes on both stresses. According to the MSAP analysis, compared control with all stress treated; lichen specimen showed different patterns of methylation under heavy metals and UV radiations stress. In comparison to saltuntreated plants, Lu et al. (2007) have detected an increase of total methylated bands in plants exposed to 50-200 mM salt. In our study, as a result of the MSAP - AFLP analyses conducted in lichen specimen exposed to different heavy metals $\left(\mathrm{Cr}^{+6}, \mathrm{~Pb}^{+2}\right.$, and $\mathrm{Cd}^{+2}$ ) and $\mathrm{UV}$ radiations (UVA, UVB, UVC, daylight, UVA + UVB, and UVA + daylight) stresses, serious changes of methylation were observed (Fig. 4).

Several studies published for determining the genotoxicity by DNA molecular markers of heavy metals exposure in cryptogams and algae so far. Sorrentino et al. (2017) were investigated by ISSR molecular markers in moss Sphagnum palustre for determining metal-induced genotoxicity. As a result of their study, both $\mathrm{Cd}$ and $\mathrm{Pb}$ salts showed a genotoxic effect with a dose-dependent trend. At concentration $>10^{-5} \mathrm{Cd}$ also induced a general toxic effect in $S$. palustre, leading to chlorophyll degradation and moss death. The 12 primers used for the analysis provided a total of 169 reproducible bands, ten of which gave polymorphisms (appearance/disappearance of bands), indicating a clear genotoxic effect induced by the metals (Sorrentino et al., 2017). In our study, some primers showed significant differences in band patterns formed by loss of normal bands and appearance of new bands in the treated heavy metals and UV radiation exposure in comparison to the untreated sample profiles. We determined a total of 138 bands using six primers to evaluate UVB radiation samples in $H$. physodes. 
Both Sphagnum palustre moss and $H$. physodes lichen species could be used as bioindicator organisms for genotoxicity.

The study evaluated the genotoxicity of MnONP in Physcomitrella patens a model plant system utilized for epigenetic alterations (Ghosh et al., 2018). DNA methylation pattern at the level of single cells was examined by the methylation-sensitive comet assay with HpaII and MspI. MnONP incited DNA hypomethylation in P. patens gametophores exposed with $20 \mu \mathrm{g} / \mathrm{mL}$ MnONP concentration. In this study, the highest rate of methylation was obtained in $H$. physodes lichen specimen stressed with UV exposure with Type-2 primer (28.9\%).

Compared with the RAPD and MSAP - AFLP analyses, the rate of change in the methylation model in lichen sample applied with heavy metal stress showed more diversity than sample applied with different UV radiations. While sample applied with heavy metal stress had a higher GTS rate in RAPD, GTS rate was determined to decrease based on the increasing UV radiations. The effect of UV stress on DNA stability was found to be higher than heavy metal stress in lichen specimen. The stability of the methylation model applied with heavy metal stress was thought to be less than UV stress in terms of epigenetics.

\section{Conclusion}

In the present study, we examined physiological and DNA damage indicator capacity of lichen specimen that has different features than other organisms. Certain organisms, such as lichens, may have properties such as being more tolerant to some pollutants than other organisms in contaminated areas or being able to accumulate the pollutant factor. These properties of organisms are used to provide qualitative information about the level of pollution in their environment. Therefore, it should be possible to make a correlation between observing and measuring the changes in the organism and the sources of the pollutant, pollution and the intensity of the pollution. This study was shown that the use of lichen specimen could eliminate the contaminants that cause environmental pollution. Detailed presentation of possible changes generated in the DNA structure and the presentation of contamination at a molecular level were ensured with our study enriched with molecular techniques. Therefore, the effect of UV stress on lichen DNA stability was thought to be greater than genetically heavy metals. The results indicated that $H$. physodes has great potential to be used in phytoremediation exercises. In addition to the properties of this lichen, the literature data has proved their antibacterial and antioxidant activity as well as cancer cell cytotoxicity and inhibitory effects on enzymes (Song et al., 2014; Mitrovic et al., 2015; Studzinska-Sroka and Zarabska-Bozjewicz, 2019). Finally, it was possible to observe the strong mechanisms of $H$. physodes lichen specimen against stressors such as heavy metals and UV radiation, allowing it to persist under highly stressful conditions. In future studies, the investigation of the biosorption capacity to accumulate different heavy metal tolerant lichen species in laboratory work still need further research. Determination of the biological response of lichens against toxic chemicals could be useful for the treatment of wastewater with lichens. These and similar studies will contribute to the identification of DNA markers. 
Acknowledgments. We thank TUBITAK (The Scientific and Technical Research Council of Turkey), Project no. 112T004 and Ankara University Project Manager, Project no. 13L4240004 for the financial support.

\section{REFERENCES}

[1] Abas, A., Sulaiman, N., Adnan, N. R., Aziz, S. A., Nawang, N. (2019): Using lichen (Dirinaria sp.) as bio-indicator for airborne heavy metal at selected industrial areas in Malaysia. - Environment Asia 12(3): 85-90.

[2] Anastassopoulou, J. (2003): Metal-DNA interactions. - Journal of Molecular Structure 651: 19-26.

[3] APHA (1985): Standard Methods for the Examination of Water and Wastewater. 16th Ed. - American Public Health Association, Washington DC.

[4] Aras, S., Cansaran-Duman, D. (2006): Isolation of DNA for sequence analysis from herbarium material of some lichen species. - Turkish Journal of Botany 30: 449-453.

[5] Aras, S., Kanlıtepe, Ç., Cansaran-Duman, D., Halıc1, M. G., Beyaztaş, T. (2010): Assesment of air pollution genotoxicity by molecular markers in the exposed samples of Pseudevernia furfuracea (L.) Zopf in the Province of Kayseri (Central Anatolia). Journal of Environmental Monitoring 12: 536-543.

[6] Ares, Á., Itouga, M., Kato, Y., Sakakibara, H. (2017): Differential metal tolerance and accumulation patterns of $\mathrm{Cd}, \mathrm{Cu}, \mathrm{Pb}$ and $\mathrm{Zn}$ in the liverwort Marchantia polymorpha $\mathrm{L}$.Bulletin of Environmental Contamination and Toxicology 100: 444-450.

[7] Aslan, A., Budak, G., Tıraşoğlu, E., Karabulut, A. (2006): Determination of elements in some lichens growing in Giresun and Ordu province (Turkey) using energy dispersive Xray fluorescence spectrometry. - Journal of Quantitative Spectroscopy and Radiative Transfer 97: 10-19.

[8] Atienzar, F. A., Conradi, M., Evenden, A. J., Jha, A. N., Depledge, M. H. (1999): Qualitative assessment of genotoxicity using random amplified polymorphic DNA: comparison of genomic template stability with key fitness parameters in Daphnia magna exposed to benzo[a]pyrene. - Environmental Toxicology and Chemistry 18: 2275-2282.

[9] Bah, A. M., Dai, H., Zhao, J., Sun, H., Cao, F., Zhang, G., Wu, F. (2011): Effects of cadmium, chromium and lead on growth, metal uptake and antioxidative capacity in Typha angustifolia. - Biological Trace Element Research 142: 77-92.

[10] Basile, A., Di Nuzzo, R. A., Capasso, C., Sorbo, S., Capasso, A., Carginale, V. (2005): Effect of cadmium on gene expression in the liverwort Lunularia cruciata. - Gene 356: 153-159.

[11] Bassam, B. J., Caetano-Anolles, G., Gresshoff, P. M. (1991): Fast and sensitive silver staining of DNA in polyacrylamide gels. - Analytical Biochemistry 195: 80-83.

[12] Benitez, A., Medina, J., Vasquez, C., Loaiza, T., Luzuriaga, Y., Calva, J. (2019): Lichens and bromeliads as bioindicators of heavy metal deposition in Ecuador. - Diversity 11: 28.

[13] Bradford, M. M. (1976): A rapid and sensitive method for the quantitation of microgram quantities of protein utilizing the principle of protein-dye binding. - Analytical Biochemistry 72: 248-254.

[14] Branquinho, C., Brown, H. D., Catarino, F. (1997): The cellular location of $\mathrm{Cu}$ in lichens and its effect on membrane integrity and chlorophyll fluorescence. - Environmental and Experimental Botany 38: 165-179.

[15] Brown, B. A., Jenkins, G. I. (2008): UV-B signaling pathways with different fluence-rate response profiles are distinguished in mature Arabidopsis leaf tissue by requirement for UVR8, HY5, and HYH. - Plant Physiology 146: 576-588.

[16] Brown, B. A., Cloix, C., Jiang, G. H., Kaiserli, E., Herzyk, P., Kliebenstein, D. J., Jenkins, G. I. (2005): UV-B-specific signaling component orchestrates plant UV 
protection. - Proceedings of the National Academy Science of the United States of America 102: 18225-18230.

[17] Cansaran-Duman, D. (2011): Study on accumulation ability of two lichen species (Hypogymnia physodes (L.) Nyl and Usnea hirta (L.) Weber ex F. H. Wigg) at iron-steel factory site, Turkey. - Journal of Environmental Biology 32: 839-844.

[18] Cansaran-Duman, D., Aras, S. (2014): Alternative Biosorbent for Biosorption: Lichens A Review. - In: Ahmed, E. (ed.) Phytoremediation. Springer, UK.

[19] Cansaran-Duman, D., Beyaztaş, T., Atakol, O., Aras, S. (2011): Assessment of the air pollution genotoxicity by RAPD in Evernia prunastri L. Ach. province of iron-steel factory in Karabük, Turkey. - Journal of Environmental Sciences 23: 1171-1178.

[20] Casano, L. M., Braga, M. R., Alvarez, R., del Campo, E. M., Barreno, E. (2015): Differences in the cell walls and extracellular polymers of the two Trebouxia microalgae coexisting in the lichen Ramalina Farinacea are consistent with their distinct capacity to immobilize extracellular Pb. - Plant Science 236: 195-204.

[21] Cheloni, G., Cosio, C., Slaveykova, V. I. (2014): Antagonistic and synergistic effects of light irradiation on the effects of copper on Chlamydomonas reinhardtii. - Aquatic Toxicology 155: 275-282.

[22] Chettri, M. K., Cook, C. M., Vardaka, E., Sawidis, T., Lanaras, T. (1998): The effect of $\mathrm{Cu}, \mathrm{Zn}$ and $\mathrm{Pb}$ on the chlorphyll content of the lichens Cladonia convolute and Cladonia rangiformis. - Environmental and Experimental Botany 39: 1-10.

[23] Cho, U. H., Seo, N. H. (2005): Oxidative stress in Arabidopsis thaliana exposed to cadmium is due to hydrogen peroxide accumulation. - Plant Science 168: 113-120.

[24] Doğan, M., Saygideğer, S. D. (2009): Effect of lead toxicity on aquatic macrophyte Elodea canadensis Michx. - Bulletin of Environmental Contamination and Toxicology 83: 249-254.

[25] Duman, F., Şahan, S., Ceylan, A., Koca, F. D. (2010): $\mathrm{Cr}^{+6}$ ya maruz bırakılmış Ceratophyllum demersum L.'nin biyolojik cevabi. - Süleyman Demirel Üniversitesi Journal of Science 5: 163-171 (in Turkish).

[26] Fernandez, M. A., Martinez, L., Segarra, M., Garcia, J. C., Espiell, F. (1992): Behavior of heavy metals in the combustion gases of urban waste incinerators. - Environmental Science and Technology 26(5): 1040-1047.

[27] Frohnmeyer, H., Staiger, D. (2003): Ultraviolet-B radiation-mediated responses in plants. - Plant Physiology 133: 1420-1428.

[28] Ghosh, I., Sadhu, A., Moriyasu, Y., Bandyopadhyay, M., Mukherjee, A. (2018): Manganese oxide nanoparticles induce genotoxicity and DNA hypomethylation in the moss Physcomitrella patens. - Mutation Research/Genetic Toxicology and Environmental Mutanegenis. https://doi.org/10.1016/j.mrgentox.2018.12.006.

[29] Gill, R. A., Zang, L., Ali, B., Farooq, M. A., Cui, P., Yang, S., Ali, S., Zhou, W. (2015): Chromium induced physio-chemical and ultrastructural changes in four cultivars of Brassica napus L. - Chemosphere 120: 154-164.

[30] Gurbanov, R., Unal, D. (2018): The biomolecular alterations in Cladonia convoluta in response to lead exposure. - Spectroscopy Letters 51(10): 563-570.

[31] Hideg, E., Jansen, M. A. K., Strid, A. (2013): UV-B exposure, ROS, and stress: inseparable companions or loosely linked associates? - Trends in Plant Science 18: 107115.

[32] Jenkins, G. I. (2009): Signal transduction in response to UV-B radiation. - Annual Review of Plant Biology 60: 407-431.

[33] Karakoti, N., Bajpai, R., Upreti, D. K., Mishra, G. K., Srivastava, A., Nayaka, S. (2014): Effect of metal content on chlorophyll fluorescence and chlorophyll degradation in lichen Pyxine cocoes (Sw.) Nyl.: a case study from Uttar Pradesh, India. - Environmental Earth Sciences 71: 2177-2183.

[34] Koroleva, Y., Revunkov, V. (2017): Air pollution monitoring in the South-East Baltic using the epiphytic lichen Hypogymnia physodes. - Atmosphere 8: 119. 
[35] Körpe-Aksoy, D., Aras, S. (2010): Evaluation of copper stress on eggplant (Solanum melongena L.) seedlings at molecular and population levels using various biomarkers. Mutation Research 719: 29-34.

[36] Kurelec, B. (1993): The genotoxic diseases syndrome. - Marine Environmental Research 35: 341-348.

[37] Larsson, P., Vecerova, K., Cempirkova, H., Solhaug, K. A. (200): Does UV-B influence biomass growth in lichens deficient in sun-screening pigments? - Environmental and Experimental Botany 67: 215-227.

[38] Li, M., Liu, Z., Xu, Y., Cui, Y., Li, D., Kong, Z. (2009): Comparative effects of Cd and $\mathrm{Pb}^{+2}$ on biochemical response on DNA damage in the earthworm Eisenia foetida (Annelida, Oligochaeta). - Chemosphere 74: 621-625.

[39] Liu, W., Li, P. J., Qi, X. M., Zhou, Q. X., Zheng, L., Sun, T. H., Yang, Y. S. (2005): DNA changes in barley (Hordeum vulgare) seedlings induced by cadmium pollution using RAPD analysis. - Chemosphere 61: 158-167.

[40] Lu, G. Y., Wu, X. M., Chen, B. Y., Gao, G. Z., Xu, K. (2007): Evaluation of genetic and epigenetic modification in rapeseed (Brassica napus) induced by salt stress. - Journal of Integrative Plant Biology 49: 1599-1607.

[41] Mackerness, S. A. H. (2000): Plant responses to ultraviolet-B (UV-B: 280-320 nm) stress: what are the key regulators? - Plant Growth Regulation 32: 27-39.

[42] Mastan, S. G., Rathore, M. S., Bhatt, V. D., Yadav, P., Chikara, J. (2012): Assessment of changes in DNA methylation by methylation-sensitive amplification polymorphism in Jatropha curcas L. subjected to salinity stress. - Gene 508: 125-129.

[43] Mateos, A. C., Amarillo, A. C., Carreras, H. A., González, C. M. (2018): Land use and air quality in urban environments: human health risk assessment due to inhalation of airborne particles. - Environmental Research 161: 370-380.

[44] Matos, P., Pinho, P., Aragon, G., Martinez, I., Nunes, A., Soares, A. M. V. M., Branquinho, C. (2015): Lichen traits responding to aridity. - Journal of Ecology 103: 451-458.

[45] Metzner, H., Rau, H., Senger, H. (1965): Untersuchungen zur Synchronisierbarkeit einzelner Pigment-Mangelmutanten von Chlorella. - Planta 65: 186 (in German).

[46] Mirouze, M., Paszkowski, J. (2011): Epigenetic contribution to stress adaptation in plants. - Current Opinion in Plant Biology 14: 267-274.

[47] Mitrovic, T. L., Stamenkovic, S. M., Cvetkovic, V. J., Radulovic, N. S., Mladenovic, M. Z., Stankovic, M. S., Topuzovic, M. D., Radojevic, I. D., Stefanovic, O. D., Vasic, S. M., Comic, L. R., Seklic, D. S., Obradovic, A. D., Markovic, S. D. (2015): Contribution to the knowledge of the chemical composition and biological activity of the lichens Cladonia foliacea Huds. (Wild.) and Hypogymnia physodes (L.). - Oxidation Communication 38: 2016-2032.

[48] Monnet, F., Vaillant, N., Vernay, P., Coudret, A., Sallanon, H., Hitmi, A. (2001): Relationship between PSII activity, $\mathrm{CO}_{2}$ fixation, and $\mathrm{Zn}, \mathrm{Mn}$ and $\mathrm{Mg}$ contents of Lolium perenne under zinc stress. - Journal of Plant Physiology 158: 1137-1144.

[49] Pandey, V., Dixit, V., Shyam, R. (2005): Antioxidative responses in relation to growth of mustard (Brassica juncea cv. Pusa Jai Kisan) plants exposed to hexavalent chromium. Chemosphere 61: 40-47.

[50] Pescott, O. L., Simkin, J. M., August, T. A., Randle, Z., Dore, A. J., Botham, M. S. (2015): Air pollution and its effects on lichens, bryophytes, and lichen-feeding Lepidoptera: Review and evidence from biological records. - Biological Journal of the Linnean Society 115: 611-635.

[51] Pisani, T., Munzi, S., Paoli, L., Backor, M., Kovácik, J., Piovar, J., Loppi, S. (2011): Physiological effects of mercury in the lichens Cladonia arbuscula subsp. Mitis (Sandst.) Ruoss and Peltigera rufescens (Weiss) Humb. - Chemosphere 82: 1030-1037. 
[52] Pourrut, B., Jean, S., Silvestre, J., Pinelli, E. (2011): Lead-induced DNA damages in Vicia fabia root cells: potential involvement of oxidative stress. - Mutation ResearchGenetic Toxicology and Environmental Mutagenesis 726: 123-128.

[53] Ramić, E., Huremović, J., Muhić-Šarac, T., Đug, S., Žero, S., Olovčić, A. (2019): Biomonitoring of air pollution in Bosnia and Herzegovina using epiphytic lichen Hypogymnia physodes. - Bulletin of Environmental Contamination and Toxicology 102: 763-769.

[54] Rein, T., Zorbas, H., De Pamphilis, M. L. (1997): Active mammalian replication origins are associated with a high-density cluster of $\mathrm{mCpG}$ dinucleotides. - Molecular Cell Biology 17: 416-426.

[55] Ronen, R., Galun, M. (1984): Pigment extraction from lichens with dimethyl sulfoxide (DMSO) and estimation of chlorophyll degradation. - Environmental and Experimental Botany 24: 239-245.

[56] Shakoor, M. B., Ali, S., Hameed, A., Farid, M., Hussain, S., Yasmeen, T., Najeeb, U., Bharwana, S. A., Abbasi, G. H. (2014): Citric acid improves lead (pb) phytoextraction in brassica napus L. by mitigating pb-induced morphological and biochemical damages. Ecotoxicology and Environmental Safety 109: 38-47.

[57] Shugart, L., Theodorakis, C. (1994): Environmental genotoxicity: probing the underlying mechanisms. - Environmental Health Perspective 102: 13-17.

[58] Singh, V. P., Srivastava, P. K., Prasad, S. M. (2012): Differential effect of UV-B radiation on growth, oxidative stress and ascorbate-glutathione cycle in two cyanobacteria under copper toxicity. - Plant Physiology and Biochemistry 61: 61-70.

[59] Song, Y., Sun, H., Zhang, A., Yan, G., Han, Y., Wang, X. (2014): Plant-derived natural products as leads to anti-cancer drugs. - Journal of Medicinal Plant and Herbal Therapy Research 2: 6-15.

[60] Sorrentino, M. C., Capozzi, F., Giordano, S., Spagnuolo, V. (2017): Genotoxic effect of $\mathrm{Pb}$ and $\mathrm{Cd}$ on in vitro cultures of Sphagnum palustre: an evaluation by ISSR markers. Chemosphere 181: 208-215.

[61] Studzinska-Sroka, E., Zarabska-Bozjewicz, D. (2019): Hypogymnia physodes-A lichen with interesting medicinal potential and ecological properties. - Journal of Herbal Medicine. https://doi.org/10.1016/j.hermed.2019.100287.

[62] Vardar, Ç., Başaran, E., Cansaran-Duman, D., Aras, S. (2014): Assessment of air pollution genotoxicity in the province of Kayseri (Central Anatolia) by using Pseudevernia furfuracea (L.) Zopf and AFLP markers. - Mutation Research/Genetic Toxicology and Environmental Mutagenesis 759: 43-50.

[63] Wellburn, A. R. (1994): The spectral determination of chlorophylls a and b, as well as total carotenoids, using various solvents with spectrophotometers of different resolution. - Journal of Plant Physiology 144: 307-313.

[64] Xu, M., Li, X., Korban, S. S. (2000): AFLP based detection of DNA methylation. - Plant Molecular Biology Reporter 18: 361-368.

[65] Zulaini, A. A. M., Muhammad, N., Asman, S., Hashim, N. H., Jusoh, S., Abas, A., Jusof, H., Din, L. (2019): Evaluation of transplanted lichens, Parmotrema tinctorum and Usnea diffracta as bioindicator on heavy metals accumulation in southern peninsular Malaysia. Journal of Sustainability Science and Management 14(4): 1-13. 